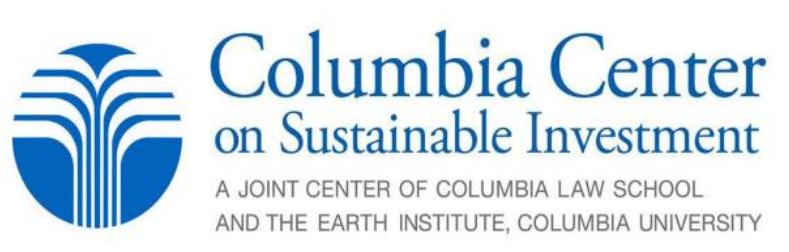

\title{
The Policy Implications of Third-Party Funding in Investor-State Dispute Settlement
}

\author{
Brooke Guven and Lise Johnson*
}

May 2019

\section{CCSI Working Paper 2019}

*Brooke Guven is a legal researcher at the Columbia Center on Sustainable Investment (CCSI) and Lise Johnson is head of Investment Law and Policy at CCSI.

The authors would like to thank Richmund St. Lucia, Stephen Dietz and Ana Valls for their research assistance, the participants of the roundtable hosted by CCSI and The International Council for Commercial Arbitration (ICCA)-Queen Mary Task Force on Third-Party Funding on October 17, 2017 for their open discussion of the issues presented, and Frank Garcia for his thought leadership and effort to broaden discussions on the issue of third-party funding. 


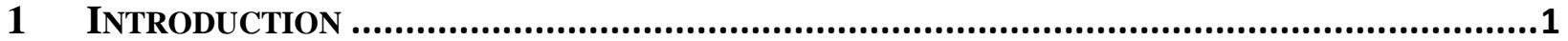

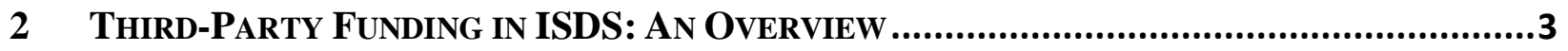

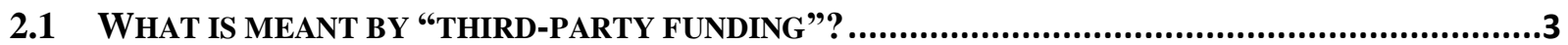

2.2 WHEN AND HOW IS THIRD-PARTY FUNDING USED IN ISDS? ..............................................

2.2.1 Claimant funding ............................................................................................

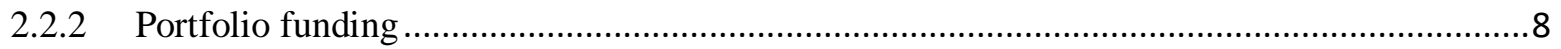

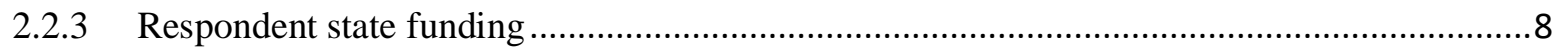

3 HOW DO WE EVALUATE THIRD-PARTY FUNDING IN ISDS? .......................................11

3.1 IMPACTS OF THIRD-PARTY FUNDING ON INVESTOR DECISIONS AND CONDUCT ....................12

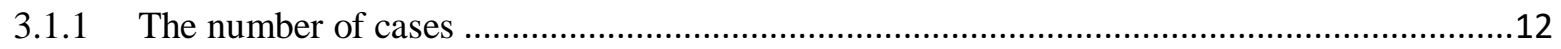

3.1.2 The nature and motives of the claimant ...........................................................................15

3.1.3 Investors' decisions to remain engaged in the host-country or exit......................................18

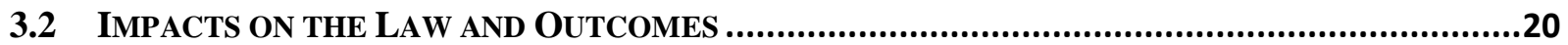

3.2.1 Impacts on the quality of cases: frivolous and marginal cases ...........................................21

3.2.2 Impacts on the substantive development of investment law .............................................25

3.2.3 Impacts on decisions to settle claims ...........................................................................28

3.3 IMPACTS ON RESPONDENT STATES AND THEIR GOVERNANCE OF INVESTMENT ....................33

3.3.1 Impacts on state conduct: regulatory chill and overdeterrence.............................................3

3.3.2 Impacts on governance of certain types of investments ………………………………......35

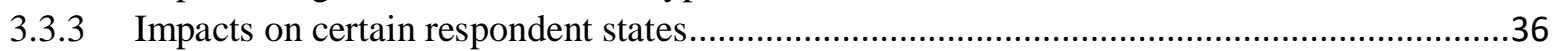

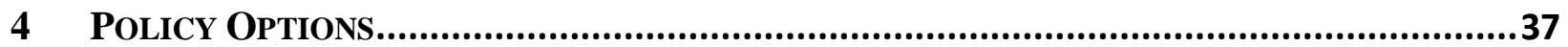

4.1 BAN THIRD-PARTY FUNDING IN FULL OR IN PART ……..................................................

4.2 REGULATE THIRD-PARTY FUNDING ...............................................................................

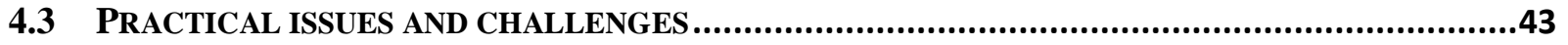

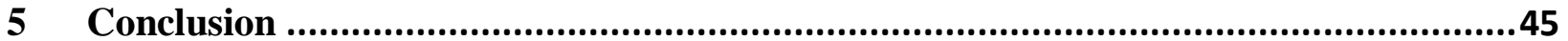




\section{INTRODUCTION}

Increasingly, investors suing governments in treaty-based investor-state arbitration (ISDS) are turning to third parties to finance their litigation. In many cases, in exchange for investing in the arbitral proceeding, the "third-party funder" will be entitled to a return or other financial interest in the outcome of the dispute, which may take the form of a share of the award. Some funders may also have contractual rights to remain involved in, and potentially even control, certain aspects of how the case is managed by the investor-claimant.

Litigation financing services can be attractive to claimants because they permit the monetization of potential assets embedded in specific, pre-award claims that are not easily accounted for or securitized. Of course, granting a third-party an interest in an illiquid asset in exchange for its financial investment requires pursuing the claim in order to realize the liquid asset. In some cases, these claims may otherwise be cost prohibitive or outside of allocated budgetary constraints of corporate (or in some cases, individual) claimants to pursue, and in others, financing a claim in this way may simply be the most efficient allocation of financial resources available to the claimant.

Recent years have seen significant increases in the number of funders and the number of funded ISDS cases. ${ }^{1}$ However, in many cases third-party funding of ISDS cases remains largely unregulated at the treaty level as well as under applicable arbitration rules. As a result, third-party funding in investment arbitration has increasingly drawn the attention of state trade and investment negotiators, arbitral tribunals, civil society, academic commentators, counsel, and funders.

The increased use of third-party funding in ISDS raises various policy issues, many of which are unique to this specific context in which claimants are permitted to sue states in ad hoc arbitration (as distinct from the use of third-party funding in litigation or arbitration between private parties under domestic law or contract). Several initiatives have been advanced to identify and analyze some of these concerns, looking for example at implications for conflicts of interests, confidentiality, control of litigation strategy and settlement decisions, and the state's ability to recover costs. Some treaties, arbitration rules, and domestic laws have implemented or are considering solutions to attempt to address some of these issues. ${ }^{2}$

\footnotetext{
${ }^{1}$ International Council for Commercial Arbitration (ICCA), Report of the ICCA-Queen Mary task force on thirdparty funding in international arbitration (2018) 4 [hereinafter ICCA-QM Report].

${ }^{2}$ E.g. Investment Protection Agreement (European Union and its Member States and Socialist Republic of Viet Nam) (not yet in force) art 2; Comprehensive Economic and Trade Agreement (CETA) (European Union and its Member States and Canada) (provisionally entered into force 21 Sept. 2017) art 8.1. Singapore has legalized third-party funding in arbitration pursuant to the Civil Law Act and has included disclosure rules pursuant to the Legal Professional Act. Singapore Civil Law Act 1999, c. 43, § 5A-5B (as amended 1 March 2017); Singapore Legal Profession Act 2001, c. 161, § 71; Singapore Legal Profession (Professional Conduct) Rules 2015, § 49A-49B. Hong Kong also permits thirdparty funding and requires certain disclosures. Hong Kong Arbitration Ordinance, No. 6, (2017), § 98(U). For an overview of various trends in approaches to and regulation of third-party funding in investment arbitration see ICCAQM Report (n 1) 55-62, 102-03; Nikolaus Pitkowitz (ed), Handbook on Third Party Funding in Investment Arbitration (Juris 2018). ICSID's rule amendment project is considering approaches to regulation of third-party funding, but its purpose is limited to conflicts of interest between the third-party funder and arbitrators and it will not address broader concerns about third-party funding. ICSID, Proposals for Amendment of the ICSID Rules, Working Paper \#2, Volume 1 (March 2019) para 128. UNCITRAL's Working Group III on ISDS Reform discussed third-party funding at its $37^{\text {th }}$ Session in April 2019 and determined that the third-party funding in ISDS is a concern of the Working Group meriting
} 
While these initiatives have helped to shed light on the practice and inform the debate surrounding the role and implications of third-party funding in ISDS, many fundamental policy issues have not yet been adequately addressed, but are nonetheless critical to inform any comprehensive analysis of the impacts and implications of third-party funding in the ISDS context. This policy paper is intended to provide an overview of issues that are paramount to states and other stakeholders regarding the use and public policy implications of third-party funding in ISDS, which in this context is unique from other dispute resolution systems in critical ways explored below. It analyzes arguments for and against third-party funding in ISDS and takes a step back to assess certain fundamental questions: What are the objectives of third-party funding in ISDS? What are its costs? What are its benefits? How do the objectives, costs and benefits vary by stakeholder? Is third-party funding desirable as a matter of public policy? If so, under what circumstances? More fundamentally, what are the criteria against which we should be evaluating its desirability? What information do we need that we do not currently have in order to answer these questions? Where information is lacking, what assumptions should be made?

With more thorough consideration of these questions, states can better determine whether and under what, if any, conditions third-party funding is acceptable and permissible; and can consider what tools are available, or should be available, to ensure third-party funding in ISDS, if permitted, serves intended aims, and does not have unintended and undesirable effects. In some cases, it may be that more information is needed to answer these questions, in which case it is critical to both decide how to regulate in the face of such uncertainty, and strive to close knowledge gaps that can be used to improve policy responses over time.

In terms of structure, Part II provides an overview of what is meant by third-party funding and how it is used in ISDS, and identifies the type of third-party funding this paper concentrates on and the reasons why it does so. Part III sets forth potential impacts of third-party funding that should inform analysis of whether and under what circumstances third-party funding of ISDS claims should be permitted. In particular, it proposes looking at whether and to what extent the involvement of third-party funding aligns with, or departs from, the core aim of investment treaties, which we articulate as promoting sustainable cross-border investment and treatment thereof. We focus on three main categories of impacts of third-party funding: Impacts on investor conduct, including decisions to sue and decisions to divest; impacts on the law and outcomes, in particular impacts on factors affecting win-loss rates and settlement decisions; and impacts on government conduct, including risks of deterring desirable government conduct. In Part IV, we set forth some considerations, options and issues for policymakers, and explore some of the barriers to action. Part V concludes.

multilateral reform, and will thus form part of the Working Group's next phase of work in which it assesses identified concerns and crafts responses to such concerns. UNCITRAL, Report of Working Group III (Investor-State Dispute Settlement Reform) on the work of its thirty-seventh session (New York, 1-5 April 2019) A/CN.9/970 (9 April 2019) paras 17-25. The report and audio recording of the $37^{\text {th }}$ Session is available at <https://uncitral.un.org/en/working_groups/3/investor-state>. The UNCITRAL Secretariat published a Note on thirdparty funding in ISDS for use by the Working Group during its $37^{\text {th }}$ Session discussions. A/CN.9/WG.III/WP.157 (24 January 2019) <http://undocs.org/en/A/CN.9/WG.III/WP.157> accessed 26 April 2019. 
This section will consider what is meant by third-party funding, and when and how third-party funding is, or is not, used in ISDS.

\subsection{WHAT IS MEANT BY "THIRD-PARTY FUNDING"?}

Third-party funders (as the term is used in this paper), are investment funds. In the context of ISDS, the investments are the potential value of treaty-based legal dispute outcomes. In exchange for investing in the claim, such that funds will be used to pay the expenses that a claimant incurs in pursuing the claim and enforcing an award, ${ }^{3}$ the funder takes an interest in an eventual financial award on a non-recourse basis. ${ }^{4}$ A successful funder's business model depends on deep expertise in understanding the strength of legal claims, appreciating how a tribunal is likely to apply applicable law to the particular facts of the case, and in providing expertise in case management and strategy, as well as in the enforcement of awards.

Underneath these broad descriptive strokes, however, more precise definitions of what, exactly, is encompassed by "third-party funding," and who, exactly, is a "third-party funder" are subject to definitional challenges. The "Report of the ICCA-Queen Mary Task Force on Third-Party Funding in International Arbitration" (the ICCA-Queen Mary Report) sets forth an exhaustive survey of various working definitions and applications, making more clear the reasons for which a universally accepted meaning continues to elude agreement. ${ }^{5}$ For one, quintessential third-party funding can resemble, be co-terminus with, or complement other forms of arbitration financing, such as contingency fee arrangements, or pro bono legal services, where services of value are also provided to a party to a dispute by an unrelated third-party. ${ }^{6}$ Further, insurance, whether obtained before a litigable event has arisen, or after the fact, can be obtained to fund arbitral claims. ${ }^{7}$ Relatedly, a wide range of debt, equity, and other risk-avoidance or funding models are rapidly evolving and continue to expand funding structures. ${ }^{8}$ While there are important distinctions among the archetype of each funding model, lines become blurred around the edges. Furthermore, the role of a funder and the structure and amount of investment made may vary significantly by claim. Some third-party funders may fund only a portion of costs, while others may fund all costs, and may become involved early in the process or much later. ${ }^{9}$ Some funders take a hands-off approach with respect to how the claim is managed, and some want to be more intimately involved in critical decision-making.

Some analyses of third-party funding use a relatively narrow definition of case-specific, nonrecourse investment by an unrelated (non-law firm) third-party while some adopt a broader definition that also takes account of other forms of financing that are functionally similar and

\footnotetext{
${ }^{3}$ Expenses paid by the funder will be capped and/or require funder management and approval.

${ }^{4}$ Non-recourse means that the funder does not have a right of action against the party to whom the financing was provided if the case is unsuccessful and does not have broader rights against the party if the amount of the award is insufficient to cover costs advanced.

${ }^{5}$ ICCA-Queen Report (n 1) 45-80.

${ }^{6}$ Ibid 36.

${ }^{7}$ Ibid After the event insurance, addressed later, is indeed looked at as a way to provide respondent funding.

${ }^{8}$ Ibid 36-37.

${ }^{9}$ Ibid 37.
} 
provided in the same market for arbitration financing, including insurance products, legal contingency fee arrangements, or philanthropic or pro bono situations. The analysis below takes a narrow approach to third-party funding given the particular issues and concerns it raises.

The narrow category of funding that is provided on a non-recourse basis in exchange for a success fee or other monetary remuneration that is wholly or partially dependent on the outcome of the claim (or a portfolio of claims, and excluding law firm contingency arrangements), as will be further discussed throughout this paper, is particularly problematic because of the ways in which it can alter incentives to sue, exacerbate existing disparities in bargaining power, financial and technical capacity, and affect outcomes of claims in favor of claimants. Other kinds of financial arrangements that are often captured by broader definitions of third-party funding do not raise the same kind of systemic and problematic concerns. For instance, with contingency fee arrangements, lawyers, like third-party funders, receive incentives to sue, and without those incentives, the underlying case might not otherwise be brought, especially when the underlying claimants are impecunious. Yet when pursuing and settling contingency fee cases, lawyers are bound to act in the interests of their clients. In contrast, third-party funding creates a new role for another actor (or, in the case of ISDS, a new financial services industry) acting in its own interests in pursuit of a financial award. Distinctions may also be made with recourse loans, which are secured by assets other than the potential value of the claim and are for a contractually fixed amount (i.e. not increasing with the value of any award), so a lender in that context would not have the same incentives to control a claim or push for any particular outcome.

Additionally, with respect to before-the-event insurance, the aims of insurers are largely risk mitigation. They primarily generate revenue by collecting premiums, and seek to reduce risks of loss by, among other things, using their knowledge and engagement to minimize the likelihood that covered risks will occur or that, if they occur, losses suffered will be lower than expected. ${ }^{10}$ If a covered loss does occur, the insurer may directly sue the parties responsible for causing the loss ${ }^{11}$ to recover damages paid, ${ }^{12}$ but such subrogation and recovery are not the industry's main source of revenue. ${ }^{13}$ As compared with third-party funders, before-the-event insurers are not motivated by the same primary objective of securing increased damages awards.

\footnotetext{
${ }^{10}$ Lise Johnson, et al., 'Alternatives to Investor-State Dispute Settlement' (April 2019) CCSI Working Paper.

${ }^{11}$ The right of subrogation is also justified as a tool for ensuring that the relevant wrongdoers incur the costs of their harm-causing actions. But subrogation is not permitted in all jurisdictions. In some jurisdictions, for instance, subrogation is only permitted against third parties that had been grossly negligent or had acted criminally. IBA Insurance Committee Substantive Project 2016, 'Insurers’ Rights of Recovery (Subrogation/Recourse)' (2016) 3.

${ }^{12}$ The extent of the recovery by the insurer may be more or less than it paid to the insured under its policy. The amounts paid by the insurer may also be more or less than the losses suffered by the insured. Different jurisdictions have different rules regarding who is entitled to amounts recovered in excess of amounts paid under the insurance policy. If, for instance, an IIA claim resulted in an insurance company receiving expectation damages through a subrogated claim, but the losses covered under the insurance policy were limited to a lower book value figure, who would be entitled to the difference between the IIA award and the insurance recovery, and what factors influence that determination?

${ }^{13}$ See, e.g., Daniel Ames et al., 'Estimation Errors Among Insurers: The Case of Subrogation' (2017) 40 J. Insurance Issues 159, 160. The ISDS dispute Kingsgate Consolidated v. Thailand helps illustrate these issues. Kingsgate's political risk insurance provider had originally declined to pay Kingsgate under the policy. Kingsgate sued the insurance company, and the parties agreed to a settlement whereby the insurance company would pay Kingsgate US\$55 million, a portion of the amount Kingsgate claims to have lost. Additionally, the settlement stipulates that the insurance company is to provide up to US\$3.5 to fund Kingsgate's ISDS claim against the government of Thailand. If Kingsgate is successful in its ISDS case, the parties are to share the ISDS award up to the point that the insurer
} 
In ISDS cases, third-party funders represent an additional player with an independent interest in the outcome of the claim. Concerns about the incentives that different actors in the ISDS system presently have to bring claims, and for tribunals to provide expansive interpretations of treaty obligations and remedies, have been gaining increasing traction and have motivated important reform efforts. However, reforms have yet to think critically about the role of third-party funders and their independent impacts on ISDS cases and investment law outcomes.

\subsection{When AND How IS THIRD-PARTY FUNDING USED IN ISDS?}

In order to assess and understand regulatory needs and options in the context of third-party funding, it is critical to first understand why, how, and in what contexts it is being or may be used.

\subsubsection{Claimant funding}

Claimant funding - i.e., funding for claimants to bring/maintain claims - is the arrangement that comes to mind when one thinks of a quintessential funding investment model. A funder sets up a (typically off-shore, tax-friendly) "special purpose vehicle" to facilitate its investment into the target asset, which in this case is the ISDS claim. ${ }^{14}$ The funder (via the SPV) and the claimant negotiate an investment contract, often referred to as the "funding agreement," which, along with related documentation, establishes the rights and obligations of the funder and claimant, including specifying the rights the funder may have to certain kinds of information, the funder's ability to be involved in certain aspects of the management of the claim (e.g. with respect to whether and under what circumstances settlement can or should occur), as well as termination rights of the funding arrangement. ${ }^{15}$ The contractual arrangements between the funder and the claimant will also include the grant of a security interest in the outcome of an eventual award, or other outcome-based remuneration agreement.

When considering whether to invest in a claim, funders consider the following, the respective importance of which will vary by claim and by funder: (1) demonstration of healthy claim, (2)

recovers the US\$58.5 million it paid, plus interest. Kingsgate will then be able to keep any amount awarded in excess of that roughly $\$ 120$ million threshold (not including interest). Kingsgate reported that this arrangement with its insurance provider obviated the need for it to secure third-party funding to pursue its ISDS claim. Damien Charlotin and Jarrod Hepburn, 'Australian Mining Investor Settles with Political Risk Insurer, as Both Team up to Pursue Arbitration Over Gold Mine Closure’, IA Reporter (18 March 2019).

${ }^{14}$ Notably, the creation of SPVs also has the potential effect of disguising the true beneficial owner of the SPV along with the identity and number of jurisdictions applicable to regulation of the ultimate funding entity, making regulation of funders and funding more challenging. Regulation should consider disclosure not only of the funder but also beneficial ownership and the relevant corporate structure.

${ }^{15}$ Domestic jurisdictions vary in their approach to whether and under what circumstances a funder may exert influence or control over management of the claim, with common law jurisdictions typically being more restrictive. Many civil law jurisdictions do not regulate the practice at all, although some do have regulations and/or explicitly tolerate it. Where regulated, current trends are generally becoming more open to third-party funding rather than restrictive, but some restrictions may be placed on its use. Some funders may structure a case to ensure that the funder does not have control over a case or claimant to minimize risks of challenges to (1) the lawfulness of the funding agreement (2) restrictions stemming from the law of the arbitral seat or (3) public policy concerns that may arise during the enforcement phase. Other funders, however, seek and structure deals to ensure that they have certain levels of control over the claim. See e.g. Pitkowitz (n 2) (Part II, Country Reports). 
counsel that has been selected by the claimant and how counsel will be compensated, (3) the value of the claim, (4) anticipated margin of recovery relative to the budget for funding, (5) the amount required to be advanced, (6) jurisdictional obstacles, (7) available defenses, (8) the expected nature, length and type of the proceeding, (9) existence and implications of associated claims (e.g., by other investors in the same sector impacted by the measure), (10) the possibility of settlement, (11) the identity of the respondent, and (12) ease of, or particular hurdles to, enforcement. ${ }^{16}$

Based on these criteria, claimant funding in ISDS is often an attractive proposition. On average, financing a claim costs US\$ 5 million per side. ${ }^{17}$ The economics of the investment require a potential award somewhere around a 5x-6x multiplier of costs, meaning the minimum value of a claim that would be attractive to a funder would be somewhere around US\$ 30 million. ${ }^{18}$

Claimants, and funders, in ISDS have potential for a considerable financial upside if they can prevail on a claim, particularly given the hurdles for respondents to bring successful counterclaims. Of ultimately successful ISDS claims, the average claimed (removing outliers) is nearly US\$ 300 million and amount awarded just over US\$ 120 million. ${ }^{19}$ In one case, a third-party funder made a return on investment of over 700 percent (over seven years) when it sold its stake in the ultimately successful claim in Teinver v. Argentina.$^{20}$ Notably, certain kinds of cases, such as disputes related to exploitation of mineral or fossil fuel reserves, or to long-term infrastructure deals, have the potential for significant expectation damages. ${ }^{21}$ Awards are not subject to appellate review, are only exceptionally annulled or set aside, and are highly enforceable in most countries around the

${ }^{16}$ ICCA-QM Report (n 1) 25 (citing B. M. Cremandes, "Chapter 12. Concluding Remarks" 154); see also ICCA-QM Report (n 1) 31 ("Case Assessment"). The authors also base this list on discussions with practitioners.

17 Daniel Behn \& Ana Maria Daza, 'The Defense Burden in International Investment Arbitration' (2019) PluriCourts Working Paper (forthcoming).

${ }^{18}$ ICCA-QM Report (n 1) 244 (Annex C) ("The group discussed the economics of third-party funding, noting that it costs about US\$ 5 million to finance an ISDS claim, so damages must be at least US\$30-40 million in order to make the claim financially feasible for funders.")

19 Behn \& Daza (n 17) (including all claims analyzed, including outliers, the amount claimed would be US\$ 1,476,000,000 and amount awarded US\$ 472,795,000).

${ }^{20}$ Tienver S.A., Transportes de Cercanias S. A. and Autobuses Urbanos del Sur S.A. v. The Argentine Republic, Award, ICSID Case No. ARB/09/1 (29 July 2017). Notably, prior to the award being rendered, Burford Capital had already sold its claim onto an institutional investor. The creation of a secondary, institutional market, in legal claim investments is a stated objective of Burford. Burford Capital, Burford 2018 Interim Report (2018) 9.

${ }^{21}$ See, e.g., Richard Caldwell et al., 'Valuing Natural Resources Investments', in Christina L. Beharry (ed) Contemporary and Emerging Issues on the Law of Damages and Valuation in International Investment Arbitration (Brill, Nijhoff International Investment Law Series, vol 11, 2018) 293, 294. The authors recount that, according to UNCTAD data as of July 31, 2017, roughly a quarter of all ISDS claims were "natural resources disputes" relating to extraction of oil and natural gas, mining and quarrying, and renewables. The authors also found that the share of such "natural resources disputes" in the total mix of cases has been higher in cases filed since 2010, and that the natural resource cases that have been filed present "exceptionally large" damages claims. We come to similar conclusions based on a search of UNCTAD's ISDS Navigator on April 10, 2019. The search indicated that most of the successful claims for over US\$100 million are related to the extractive industries or provision of infrastructure. The search produced 60 cases, the majority of which involved investments in the extractive industries, or in concessions for water, sewerage, and electricity services alone. Additional cases related to telecommunications and transportation infrastructure. In these disputes, the tribunals often calculate damages by looking, inter alia, at future lost profits over the duration of the concession or expected life of the project, which may extend decades. See, e.g., Antin Infrastructure Services Luxembourg v. Spain, Award, ICSID Case No. 13/13/31, June 15, 2018, para 689-691, 714; Karkey Karadeniz Elektrik Uretim v. Pakistan, Award, ICSID Case No. ARB/13/1, August 22, 2017, para 664. 
world pursuant to the New York and ICSID Conventions. ${ }^{22}$ ICSID and UNCITRAL proceedings are reported to take roughly 3-4 years from initiation through to the issuance of an award ${ }^{23}$ which means a relatively short and concrete time frame for an investment to mature. Moreover, states, unlike corporate defendants in other fora, cannot declare bankruptcy. While a successful claimant may ultimately take a discount on the award (or sell the award on to another enforcement/collection fund or investor for a discount) it is still likely to collect something. ${ }^{24}$

Furthermore when looking at the outcome of ISDS claims in the aggregate, claimants appear to have a good track record. ${ }^{25}$ In roughly two-thirds of all claims, claimants prevail or the state settles, which means that in roughly two-thirds of the time the claimant walks away with compensation or another remedy. ${ }^{26}$

${ }^{22}$ These are, respectively, the Convention of 1958 on the Recognition and Enforcement of Foreign Arbitral Awards, (adopted 10 June1958, entered into force 7 June 1959) 21 U.S.T 2517, 330 U.N.T.S. 38 [hereinafter New York Convention], and the International Convention on the Settlement of Investment Disputes Between States and Nationals of Other States, (adopted 18 March 1965, entered into force 14 October 1966) 17 U.S.T. 1270, 575 U.N.T.S. 159, art 37(2)(b) [hereinafter ICSID Convention]. New York Convention awards may even be enforced when set aside at the seat. See, e.g., Alessandra Sardu, 'The Fate of the Award Annulled in the Country of the Seat' (2016) 17 Global Jurist 1 .

${ }^{23}$ UNCITRAL, 'Note by the Secretariat: Possible Reform of Investor-State Dispute Settlement (ISDS -Cost and Duration)' (31 August 2019) A/CN.9/WG.III/WP.153, para 54-59. "Initiation" as used above in the text means the time of registration for ICSID and the notice of arbitration for UNCITRAL.

${ }^{24}$ See, e.g., Blue Ridge Invs. v. Argentina, 735 F.3d 72, 77 (2013, amended 2014) (noting that the claimant in CMS v. Argentina sold its interest in the award against Argentina to Blue Ridge Investments).

${ }^{25}$ It must be acknowledged, however, that it is difficult to tell much from basic win/loss rates. For instance, indirect or regulatory takings claims under US law, which are similar to ISDS claims for indirect expropriation, have a relatively low success rate. See, e.g., Carol Necole Brown \& Dwight H. Merriam, 'On the Twenty-Fifth Anniversary of Lucas, Making or Breaking the Takings Claim' (2017) 102 IowA L. REV. 1847 (finding a 1.6\% success rate for "Lucas-type" takings claims, in which the government is alleged to have wiped out all economically beneficial or productive use of land); James E. Krier \& Stewart E. Sterk, 'An Empirical Study of Implicit Takings' (2016) William \& Mary L. Rev. 35 (categorizing different types of takings cases, finding low-success rates across the different categories (i.e., Lucas, Penn-Central, exaction, and other), albeit with some variations, and concluding that the "courts almost always defer to the regulatory decisions made by government officials, resulting in an almost categorical rule that Penn Central-type regulatory actions do not amount to takings"); Adam R. Pomeroy, 'Penn Central After 35 Years: A Three-Part Balancing Test or a One Strike Rule?' (2013) 22 FED. CIR. B.J. 677, 692 (finding a roughly 12\% success rate for cases decided on the merits; the success rate drops to $4 \%$ when considering cases that were dismissed on jurisdictional grounds). There are various reasons why win-loss rates don't necessarily reflect how favorable or biased a legal system may be toward one side or another. If, for instance, there were clear, strict, and constantly enforced requirements for claims to be based on detailed pleadings backed up by facts, one might expect that the cases brought would stand relatively good chances of success; alternatively, if the door to the "court" or tribunal is relatively open, the win-rate might be relatively low. While the issue requires more analysis, it appears that ISDS claims are more of the latter, open-door variety, since there are no strict requirements to plead cases with particularity, and, as they have been applied, standards for dismissal of frivolous claims appear relatively weak. Tribunals seem especially reluctant to dismiss cases on the basis of initial complaints alone without providing the opportunity for further discovery and factual submissions.

${ }^{26}$ Behn \& Daza (n 17). Some settlements do not involve monetary remedies but regulatory or other concessions. See e.g. Dow AgroSciences LLC. V. Government of Canada, Settlement Agreement (25 May 2009) (A US chemical manufacturer gave notice that it would challenge the Quebec Pesticides Management Code seeking \$2 million based on alleged lack of due process in passage of the law and damage to Dow's investment in Canada. Canada's law banned and regulated the spraying of certain cosmetic pesticides for environmental and health reasons. Canada settled with Dow. The settlement did not involve a payout to Dow, but the Quebec government apparently agreed to a statement that "products containing [the banned chemical] do not pose an unacceptable risk to human health or the environment, provided that the instructions on their label are followed."). Even nonmonetary settlements can have significant 


\subsubsection{Portfolio funding}

While funders may invest in single claims, "portfolio" funding is increasing. ${ }^{27}$ A portfolio arrangement is one in which a funder takes a financial interest in a basket of claims, which may be focused around the same claimant, or around the same law firm, ${ }^{28}$ such that the funder's return is dependent upon the overall net performance of the portfolio (or several portfolios) and thus less impacted by any particular claim. ${ }^{29}$ This arrangement benefits the funder as it is able to diversify its investment risk, and thus can also result in a lower cost of funding capital for a claimant, which for funders and claimants is a win-win situation. As IMF Bentham, a publicly-traded third-party funder, explains, "Portfolio investing allows costs and risks to be collateralized across the cases within the portfolio, with a commensurate reduction in return. Investment in single-party cases generally involves greater risk, given the binary nature of the outcome, but concurrently delivers greater returns." 30

Moreover, the ability to bundle claims permits securitization and the creation of a secondary market in those claims. While institutional investors do not have the time, expertise, or specialization to invest in claims directly, the ability to invest in a risk-adjusted bundle of claims may present an attractive alternative capital outlet. Funders are actively seeking to create these kinds of securities to expand investment capital and mitigate funder risk, ${ }^{31}$ and it appears that there is already some level of a secondary market for investments in ISDS claims. ${ }^{32}$ For these reasons, absent any regulation, portfolio funding is likely to continue, and increase.

\subsubsection{Respondent state funding}

Respondent funding differs considerably from claimant funding because (1) under nearly all existing treaties states cannot initiate but can only defend claims, and (2) the possibility of counterclaims is limited. Therefore, states do not have a financial "upside"; the best financial position that a respondent state can usually hope for as an outcome is an award for $100 \%$ of its costs, with interest, and recovery for reputational harm (e.g. as a safe destination for foreign direct

monetary value, though it is unclear that such value can always be monetized and alienated. A settlement that exempted a company from tax liabilities or environmental requirements would, for instance, foreseeably reduce corporate expenses and increase corporate profits; other settlement terms, however, such as provisions prohibiting disparaging comments by, or requiring confidentiality of, the promisor may be of value to the promisee but difficult to quantify. See, e.g., Scott A. Moss, 'Illuminating Secrecy: A New Economic Analysis of Confidential Settlements' (2007) 105 Mic. L. Rev. 867 (discussing value of confidentiality provisions); Amos v. Comm'r, 2003 Tax Ct. Memo 2003-329 (US Tax Court, December 1, 2003) (valuing the portion of a settlement agreement that represented a nondisclosure agreement).

${ }^{27}$ See ICCA-QM Report (n 1) 38-39. E.g. Burford Capital, '2018 Annual Report' (2018) (which does not distinguish between portfolios that include ISDS claims and those that do not).

${ }^{28}$ Portfolio funding can also be structured around a law firm and its clients, but in these situations the funded party would be the law firm (and its contingency fee arrangements) and not the claimants directly.

${ }^{29}$ ICCA-QM Report (n 1) 47 ("One reason for additional complexity with law firm and portfolio funding is that one portfolio of cases can be identified to receive funding, while another portfolio is the basis for a funder's return or securitization of its investment.").

${ }^{30}$ IMF Bentham, 'Annual Report 2018' (2018) 14.

${ }^{31}$ Burford 2018 Interim Report (n 20) 9.

32 Burford 2018 Annual Report (n 27) 48, 89. 
investment), ${ }^{33}$ to be covered by the claimant. The profit potential that attracts funders to claimant positions does not and will not exist for ISDS respondents except in circumstances when contractual or other counterclaims exist. As a result, the economics of providing funding to states is a considerable challenge.

Respondent funding is a conceptually distinct product when compared to many of the forms of claimant funding, as it is, in effect, insurance. ${ }^{34}$ For example, with after-the-event ("ATE") insurance or a similar kind of arrangement, if a litigable event has occurred and a claim has arisen against the respondent, the respondent and funder could seek to agree on the valuation of the claim - how will a tribunal apply the law to the facts and what will the claimant's award be, if anything? Is the claimant likely to prevail, and if not, will the tribunal shift costs to ensure the state is reimbursed for its expenses? Is the lawsuit a \$15 million liability? A \$50 million liability? A \$2 billion liability? If the price of the downside risk can be agreed between the respondent and the funder, the respondent could then purchase a "policy" that would protect it against higher than anticipated awards. The respondent would pay a deductible for the expected judgment or settlement, and for amounts that exceed the agreed threshold, the funder would have a contractual obligation to pay. That obligation to pay an award or other amounts, such as an award for costs, is negotiated and context-specific, and so could be an obligation shared as between the state and funder based on various thresholds and permutations.

As with claimant funding, funders may also find a version of portfolio funding to be an attractive option where the losses on the ISDS defense could be offset by another portfolio of cases in which the state was pursuing contract-based or other claims (likely in other fora such as domestic courts) with opportunities for financial recovery. ${ }^{35}$

Where there are likely other ways of funding respondent claims that are being explored (or possibly implemented), third-party financing of respondent claims in ISDS seems to be, and will likely remain, more theoretical than practiced. Anecdotal evidence obtained suggests that in one case a funder and a state have agreed on a deal structure and terms. ${ }^{36}$ However, other examples have remained hard to identify and are of questionable existence. There are several reasons to be skeptical that respondent funding could be scalable: For one, states and funders may face difficulties structuring respondent-side deals due to challenges in accurately pricing down-side ISDS risk. Such a task is notoriously complex, which in no small part stems from the vague nature of substantive investment law standards, questions about the appropriate measures of compensation due for treaty breaches, ${ }^{37}$ and uncertainty and imprecision regarding the burdens of

\footnotetext{
${ }^{33}$ Todd Allee \& Clint Peinhart, 'Contingent Credibility: The Impact of Investment Treaty Violations on Foreign Direct Investment' (2011) 65 Int'l Organization 401 (calculating drops in FDI associated with even ultimately unsuccessful claims).

${ }^{34}$ Jonathan T. Molot, 'A Market in Litigation Risk' (2009) 76 U. CM. L. REV. 367, 378; ICCA-QM Report (n 1) 23. See also David Chriki, 'Investment Abitration Liability Insurance: A possible solution for concerns of a regulatory chill?' (Apr. 8, 2018) Columbia FDI Perspectives (considering before-the-event government insurance).

${ }^{35}$ See e.g. ICCA-QM Report (n 1) 246 (Annex C).

${ }^{36}$ Ibid.

${ }^{37}$ See, e.g., Noah Rubins et al., 'Approaches to Valuation in Investment Treaty Arbitration' in Christina L. Beharry (ed) Contemporary and Emerging Issues on the Law of Damages and Valuation in International Investment Arbitration (Brill, Nijhoff International Investment Law Series, vol 11, 2018) 171 (discussing approaches to valuation and implications of issues such as the valuation date and indirect and consequential losses). There are also questions about
} 
proof and production required for establishing the amount of damages suffered and owed. ${ }^{38}$ This uncertainty is exacerbated by the fact that these vague substantive and procedural standards are applied by ad hoc arbitrators in a system that applies neither precedent nor appellate review; and this uncertainty manifests itself both through inconsistent interpretations of treaty provisions and damages calculations and through the rather large gap between amounts claimed and amounts awarded ${ }^{39}$ While these factors and issues also give rise to uncertainty regarding the ultimate value of the claimant's claim, the uncertainty may be less problematic for claimant funding than respondent funding. The claimant and funders might only need comfort that the claim has a value of greater than perhaps US\$ 30 million, in light of and subject to anticipated litigation costs; with respondent funding, the task (at least with ATE insurance, but also with other portfolio structures) seemingly becomes the more challenging one of determining where along a wide spectrum a damages award will sit if liability is found.

Additionally, if the potential funding is linked to a counterclaim or claim in separate proceedings, it may be legally, politically, and/or practically difficult for the state to enter into deals giving third parties a share in recoveries the state alleges are due it (or its agencies, state-owned enterprises, citizens, or other parties). For all the talk of defense-side funding in ISDS, the reality is that any scalable and systemic approach to providing such funding through the models that look like claimant funding models, or ATE-insurance-like products, appears unlikely at this time.

Moreover, even if pricing and other hurdles to ATE insurance and other products could be overcome, the question then becomes one of control - if a funder is taking substantial down-side risk, or upside-interest in other claims, it may want a certain amount of control over critical aspects of case management, such as, for example, what arguments to raise, when to settle the claim and for how much. In corporate settings, where clear management hierarchies and defined corporate objectives apply, the granting of some level of control may make sense in some contexts. In contrast, governments, which have obligations to a wide-variety of stakeholders, have vastly different considerations. Whether and under which circumstances governments can and should (1) grant funders an interest in debt or liabilities to the state (or the state's SOEs, subnational entities, agencies, or other constituencies), and (2) grant funders a role in decisions regarding how to litigate and/or settle ISDS claims, are issues that raise important legal and policy questions, including questions of domestic law, democratic accountability and the public interest. ${ }^{40}$

The reality is that while the respondent may be able to manage and/or limit its risk, it will still need to pay something, and perhaps a considerable amount, to shift some of its otherwise largely

how these different standards apply to determine recovery that should be paid to different types of asset owners (e.g., the enterprise or indirect shareholders in it).

${ }^{38}$ Ibid 200 (noting that "some degree of subjectivity and uncertainty, while inevitable, is not a bar to recovery", a statement suggesting a relatively flexible and loose burden of proof on damages).

${ }^{39}$ Molot (n 34) 380-81 (Hurdles to accurate down-side pricing in litigation as a general matter include: "The basic question of whether litigation risk is susceptible to accurate pricing or whether litigation is just too unpredictable to price. Second, even if one could price litigation risk given complete information, there are a host of information asymmetries and adverse-selection problems that arise because those seeking to dispose of litigation risk often know more about that risk than those who would assume the risk. Third, there are work product and privilege issues that must be addressed if information is to be shared with a third party seeking to price and assume litigation risk from a defendant.")

${ }^{40}$ Lise Johnson \& Brooke Skartvedt Guven, 'The Settlement of Investment Disputes: A Discussion of Democratic Accountability and the Public Interest’ (March 13, 2017) Investment Treaty News. 
unlimited risk to a funder. As the average cost of defending a claim is US\$ 5 million, ${ }^{41}$ paying for defending against claims, even if the risk can be limited, is not a small consideration, particularly as the number of claims against states continues to grow. ${ }^{42}$

\section{HoW DO WE EVALUATE THIRD-PARTY FUNDING IN ISDS?}

ISDS is integrated in investment treaties purportedly as a mechanism to advance, not undermine those treaties' overarching objectives. It is therefore important to understand how ISDS, as a dispute settlement mechanism affects, positively or negatively, the treaties' aims. Similarly, when evaluating third-party funding of ISDS cases, it is crucial to understand whether and how this particular financial structure and the incentives created by it affects the operation of ISDS and the object and purpose of investment treaties.

In this paper, we work from the assumption that the object and purpose of investment treaties is to promote investment and shape the government's treatment of it in order to foster the sustainable economic development and prosperity of state parties and stakeholders within them, not just the economic prosperity of foreign investors. ${ }^{43}$ In this sense, investment treaties are instrumentalist agreements with two levels of desired impact. Host states commit to provide investors certain standards of treatment in order to encourage investment, which is in turn intended to advance sustainable economic development. Protection of investors is not itself the policy objective of investment treaties but is viewed as a means by which a desired objective can be achieved. ${ }^{44}$

Thus, employing the view that investment treaties aim to promote and protect foreign investment in order to advance a holistic notion of prosperity consistent with and supportive of sustainable development, we examine how the role of third-party funding may impact relevant investor and state conduct. Viewed in this way, it is important to consider the role of third-party funding of

${ }^{41}$ Behn \& Daza (n 17).

${ }^{42}$ A study by Behn \& Daza counts 1,142 known treaty and contact-based ISDS claims. Ibid. UNCTAD's Investment Policy Hub cites 942 known treaty-based claims (as of the end of 2018). Investment Dispute Settlement Navigator <https://investmentpolicyhub.unctad.org/ISDS> accessed Mar. 20, 2019. For a comparison of number of claims filed per year between 1987 and 2017, see UNCTAD, 'World Investment Report 2018: Investment and New Industrial Policies' (2018) 92. To the extent a respondent state has litigation insurance the overall cost may be reduced in that context.

${ }^{43}$ E.g. Agreement for the promotion and protection of investments (Republic of Korea and Paraguay) (entered into force Aug. 6, 1993) Preamble ("Recognizing the important complementary role of foreign investment in the economic development process..."); Treaty between the United States of America and the Argentine Republic Concerning the Reciprocal Encouragement and Protection of Investment (entered into force Oct. 20, 1994) Preamble ("Recognizing that agreement upon the treatment to be accorded such investment will stimulate the flow of private capital and the economic development of the parties"); Agreement on encouragement and reciprocal protection of investments (Kingdom of the Netherlands and the People's Republic of Bangladesh) (entered into force June 1, 1996) Preamble ("Recognizing that agreement upon the treatment to be accorded to such investments will stimulate the flow of capital and technology and the economic development of the Contracting Parties..."); Agreement between The Swiss Confederation and The Arab Republic of Egypt on the Promotion and Reciprocal Protection of Investments (entered into force May 15, 2012) Preamble ("Recognizing the need to promote and protect foreign investments with the aim to foster the economic prosperity and sustainable development of both States"); Agreement between Canada and Mongolia for the Promotion and Protection of Investments (entered into force Feb. 24, 2017) Preamble ("Recognizing that the promotion and the protection of investments of investors of one Party in the territory of the other Party will be conducive to the stimulation of mutually beneficial business activity, to the development of economic cooperation between them and to the promotion of sustainable development...").

${ }^{44}$ See Gus Van Harten, Investment Treaty Arbitration and Public Law (Oxford University Press 2008) 140. 
ISDS claims in, in particular (1) influencing investors' investment-related decisions (including decisions to reinvest or divest, decisions to sue, and decisions to settle), ${ }^{45}$ (2) shaping the contours of investment law and outcomes in particular cases, and (3) influencing governments' willingness and ability to regulate investment in order to advance sustainable development aims. We consider those issues below.

\subsection{IMPACTS OF THIRD-PARTY FUNDING ON INVESTOR DECISIONS AND CONDUCT}

This section looks at three different implications that third-party funding may have for investor conduct. These are how third-party funding may affect

- the number of cases that are brought;

- the nature and motives of the claimant; and

- investors' decisions to remain engaged in the host-country or exit.

\subsubsection{The number of cases}

Legal dispute funders create a market for litigation ${ }^{46}$ risk where there was none by allowing a party to monetize its illiquid interest in the outcome of a claim. Relatedly, funders also enable would-be litigants who do not wish to bear litigation risk to transfer some or all risk to the funder. Indeed, a funder's business model is entirely based on bearing litigation risk in exchange for rights to a financial upside.

While third-party funding is often portrayed as a means of providing access to justice for claimants who would not otherwise have funds to seek a remedy, in many and a growing number of cases, claimants seek funding not because they are impecunious but because they wish to pursue claims with as little impact on cash flows, and as great a chance of success, as possible ${ }^{47}$ These wellresourced and sophisticated claimants may seek to manage risk, may not have budgeted for the anticipated expenditure on the claim, may otherwise be seeking to reduce legal budgets or "turn legal departments into profit centers," 48 or may wish to take "off-balance sheet" the cost of pursuing legal claims. Financing a claim via a third-party funding model permits funds that may otherwise be used for litigation/arbitration to be reinvested or put to use to expand business growth and opportunities. ${ }^{49}$

\footnotetext{
${ }^{45}$ The Effect of Treaties on Foreign Direct Investment (Karl Sauvant \& Lisa Sachs eds) (Oxford University Press 2009); Joachim Pohl, 'Societal Benefits and Costs of International Investment Agreements' (2018) OECD Working Papers on International Investment, Working Paper No. 2018/1; Emma Aisbett, 'Bilateral Investment Treaties and Foreign Direct Investment: Correlation versus Causation' (2007) CUDARE Working Papers No. 1032, 2007; Lise Johnson et al., 'Costs and Benefits of Investment Treaties: Practical Considerations for States' (Columbia Center on Sustainable Investment 2018); Jonathan Bonnitcha, 'Assessing the Impacts of Investment Treaties: Overview of the Evidence' (International Institute for Sustainable Development 2017).

${ }^{46}$ We use the term "litigation" here to also include arbitration.

${ }^{47}$ ICCA-QM Report (n 1) 20.

${ }^{48}$ Ibid 21 (Setting forth the reasons for which claimants may seek out third-party funding: "As an alternative to tying up their own capital in litigation or arbitration, corporations can use dispute funding to pursue arbitrations that can help transition their in-house legal departments from cost centres to profit centres.").

${ }^{49}$ Ibid 20.
} 
Third-party funding, in short, can reduce the risk and costs claimants would otherwise face when bringing an ISDS claim. Consequently, third-party funding may tilt decision-making frameworks in favor of arbitration and can result in investors pursuing claims that absent such funding, they would have otherwise been unwilling or unable to pursue. This, in short, likely means that thirdparty funding will result in more ISDS claims being brought than would be if that funding were not available. Although, due to challenges of data availability, studies of the effects of third-party funding on the amount of claims filed are limited, available research suggests that litigation finance does in fact drive up the number of cases brought. ${ }^{50}$ Indeed, this effect of third-party funding in ISDS also seems to be acknowledged by funders, claimants' counsel, and claimants, who contend third-party funding is important for access to justice as, without it, at least some claims might otherwise not be advanced. ${ }^{51}$

Yet while third-party funding can make it possible or more attractive for investors to bring ISDS claims, it is important to highlight that access to ISDS is not synonymous with access to justice and, even if it were, access to third-party funding is not necessarily the most appropriate "access to justice" tool. For one, while there may very well be some cases in which the funder truly facilitates the ability to access a system of legal adjudication when no other effective remedy is available, in most cases ISDS is not the only procedural mechanism available to investors, nor are IIAs their only sources of substantive protections. ${ }^{52}$ Normative conceptions of access to justice and right to an effective remedy do not mean that parties have an absolute right to their most outcome- or cost-preferred remedy. ${ }^{53}$ Taking this broader view, other than in cases where domestic or other remedies have been exhausted or are actually unavailable, claims that third-party funding

\footnotetext{
${ }^{50}$ Daniel L. Chen, Can Markets Stimulate Rights? On the Alienability of Legal Claims (2015) 46 RAND J. of Economics 23, 25, 33 (using data from a litigation funder in Australia); see also David S. Abrams \& Daniel L. Chen, A Market for Justice: A First Empirical Look at Third Party Litigation Funding (2013) 15 U. PenN. J. Bus. L. 1075, 1078 (noting that funders may result in more claims being brought as they can play a role in communicating to potential claimants or firms that claims may exist).

${ }^{51}$ See, e.g., Norton Rose Fulbright, International Arbitration, Issue 7 (September 2016) 3, 9, 11; see also Chen (n 50) 33.

${ }^{52}$ Investors that benefit from IIA protections also likely have access to domestic courts and have the ability to pursue a remedy in the same way that domestic investors and other foreign investors who do not have access to IIA protection may. Based on claims filed and breaches found to date, there have been only a handful of successful claims of discrimination against foreign investors, and a similarly small set of successful claims for denials of justice. This indicates that investors are actually not using ISDS to allege systemic inadequacy of or bias in domestic courts, notwithstanding that those flaws are often cited as reasons why ISDS is important. See, e.g., Jarrod Hepburn, '2018 Developments in Investment Treaty Arbitration' in Yearbook on International Investment Law and Policy 2018 (Lisa Sachs, Lise Johnson, and Jesse Coleman, eds) (Oxford University Press 2019 (forthcoming)); research on nondiscrimination is on file with authors. Moreover, the denial of justice in domestic courts is, of course, its own international legal claim both in international investment law, but also in international human rights fora (some of which are open to claims by corporate entities). See, e.g., Lise Johnson et al., Alternatives to Investor-State Dispute Settlement (n 10) 11-14.

${ }^{53}$ Lise Johnson, Lisa Sachs and Jeffrey Sachs, 'Investor-State Dispute Settlement, Public Interest, and U.S. Domestic Law' (May 2015) CCSI Policy Paper 7-15 (setting forth examples of how and in which circumstances investment treaty protections, as enforced through ISDS, offer greater substantive rights to foreign investors in the United States when compared to otherwise applicable US law, and how procedural rights available through ISDS also lead to greater substantive rights as applied); Francesco Francioni, 'The Right of Access to Justice under Customary International Law' in Francesco Francioni (ed) Access to Justice as a Human Right (Oxford University Press 2007) 1-55, 33-54 (discussing circumstances under which access to justice may be restricted, and how to evaluate those circumstances, including: whether restrictions are assessed on the basis of reasonableness, whether the restriction has legitimate aims, whether the means used are proportionate to the legitimate aim, among others).
} 
supports "access to justice" are more accurately stated as claims that third-party funding supports "access to ISDS."

Furthermore, third-party funding is far from the only way to ensure that even impecunious investors are provided an effective remedy for actual loss. There are, for instance, financing mechanisms that operate in the same or similar market as third-party funding and may be available in situations of impecuniosity, even if on a more limited basis, such as contingency fee arrangements. ${ }^{54}$ Additionally, there are a variety of public and private entities that provide investment support, including political risk insurance. Ex ante risk insurance, such as that provided by the World Bank's Multilateral Investment Guarantee Agency, domestic insurance entities (e.g. the United States' Overseas Private Investment Corporation), and private risk insurers cover many situations that would also be covered by investment treaty standards. ${ }^{55}$ And, as noted below, these supports may not raise the same concerns as third-party funding that takes a contingent interest in the outcome of litigation.

Additionally, as indicated above, claimants reportedly often seek funding not because they are impecunious but because of other benefits that funding can offer, such as enabling claimants to take legal costs off their balance sheets and to access the resources, know-how, networks and case management expertise of the third-party funder, akin to a legal management consultant, can provide. The use of third-party funding by non-impecunious claimants to manage balance sheets and improve chances of success are not necessarily negative, but also are not "access to justice" as that term is commonly understood. This is relevant to a cost-benefit analysis of the overall importance of third-party funding to claimants and its impacts on respondent states and other stakeholders. ${ }^{56}$ If access to justice is being asserted as a rational for the use of third-party funding in ISDS, it is critical for policymakers to understand in what kind of circumstances claimants actually require this kind of critical assistance, and whether third-party funding is the only or, in light of the policy considerations raised in this paper, even most desirable way to facilitate access to an effective remedy. Empirical evidence as to why and under what circumstances third-party funding is used - evidence that is known and held by funders but not shared publicly - is critical to analyzing the costs and benefits of third-party funding and crafting policy responses, such as informing decisions on whether and how to regulate or ban it.

Overall, arguments that third-party funding is solving true access to justice problems appear at present to be more rhetoric than reality. Funders are best-placed to offer examples and data to demonstrate otherwise, but that information remains elusive. Rather, it appears that funders are

\footnotetext{
${ }^{54}$ In some cases, third-party funding interacts with these other financing mechanisms in ways that makes them more broadly available.

${ }^{55}$ Importantly, these entities incorporate screening and other mechanisms to help to ensure that beneficiaries are contributing to and not undermining various social, environmental, and human rights norms in the process of their investment. Investment treaties, on the other hand, are agnostic on these issues, protecting all covered investment regardless of its negative social, environmental, or human rights impacts on the home (e.g. offshoring of jobs or taxes) or host (e.g. environmental pollution) state. These kinds of mechanisms may be more attractive than the ex ante reliance on ISDS protections if the objective is a holistic conception of "justice." Investment treaties are effectively free political risk insurance from the perspective of the investor. See, e.g., Lise Johnson et al., Alternatives to InvestorState Dispute Settlement (n 10) 5-7.

${ }^{56}$ Tara Santosuosso \& Randall Scarlett, 'Third Party Funding in Investment Arbitration: Misappropriation of Access to Justice Rhetoric by Global Speculative Finance' (2019) 60(9) Boston College L. Rev.
} 
financing claims to pursue their own profit motives, and claimants are contracting with them for diverse financial and strategic purposes.

While funders' profit-seeking objective is not inherently objectionable and can produce beneficial spillovers by facilitating certain kinds of claims or leveling playing fields in certain asymmetrical contexts, it is also relatively uncontroversial to note that governments do not, need not, and should not necessarily sanction all profit-seeking or litigation-backing activities. In fact, and as discussed below, at least some governments have determined that they will not permit the existence of such litigation finance schemes when those schemes involve acquiring interests in claims against the government, in contrast to whether or not third-party funding is otherwise generally permitted within the jurisdiction. The rationale for and mode of restricting third-party funding in claims against the government is explained below.

\subsubsection{The nature and motives of the claimant}

Analyses of policy considerations of third-party funding in ISDS typically look, at some point, to comparisons with general domestic jurisdictions' treatment of and trends in third-party funding and its regulation. For example, in many civil law countries, the practice may be relatively new and/or unregulated, or may be expressly authorized. ${ }^{57}$ In contrast, common law jurisdictions historically prohibited maintenance, or the support of litigation by another party who lacks a legitimate interest in the lawsuit, and champerty, akin to maintenance but with the specific feature of supporting the litigation in exchange for a return of a share of the proceeds. These legal regulations grew out of a desire to prevent the wealthy or powerful from using the medieval English legal system to gain material wealth by putting power behind unmeritorious or socially undesirable claims. ${ }^{58}$

As judicial independence grew, some scholars and jurisdictions began to view these common law limitations as unnecessary. ${ }^{59}$ While some common law jurisdictions, such as Ireland, ${ }^{60}$ have strongly maintained maintenance and champerty as criminal and tort offenses, others have eliminated prohibitions under criminal law, while retaining it under tort, and others have carved out certain areas where third-party funding is permitted but regulated. ${ }^{61}$ These jurisdictions have done so in order to advance identified policy goals, such as closing gaps in access to justice for certain types of claimants or cases. Where such deregulatory steps have been taken, they are often accompanied by analysis and balancing of competing considerations. For example, many jurisdictions may permit third-party funding in some or all cases, but may still view as problematic and thus regulate certain aspects of the funded claim or the funder, such as situations in which a

\footnotetext{
${ }^{57}$ Pitkowitz (n 2) Part II: Country Reports (e.g. Brazil has no rules on third-party funding, but it is regulated within the broader context of financial services regulation; third-party funding is recognized as validly practiced in France; third-party funding in Germany is largely unregulated; the Netherlands does not have specific rules on third-party funding but the parliament is discussing what rules should apply within the broader context of allowing the practice)

${ }^{58}$ Michael K. Velchik \& Jeffrey Y. Zhang, 'Islands of Litigation Finance' (April 25, 2017) John M. Olin Center for Law, Economics, and Business, Fellows' Discussion Paper Series, Discussion Paper No. 71, 10-12.

${ }^{59}$ Ibid 12.

${ }^{60}$ Persona Digital Telephone Ltd. and Sigma Wireless Networks Ltd v The Minister for Public Enterprise \& Ors [2017] IESC 27 (Ir).

${ }^{61}$ See e.g., Nikolaus Pitkowitz, 'The TPF Handbook' in Pitkowitz (n 2); Aaron Katz \& Steven Schoenfeld, 'Third Party Litigation Financing in the US' (2018) WestLaw, Practical Law, Resource ID 5-518-1314 (discussing approaches to and rules surrounding litigation financing in US jurisdictions).
} 
funder could influence or control the management of a funded case during the course of proceedings. ${ }^{62}$

While it is generally asserted that the trend is in liberalizing, not tightening restrictions on thirdparty funding (in some cases where funders have themselves lobbied for such changes), ${ }^{63}$ there are examples of jurisdictions that are seeking to regulate third-party funding in contexts where it simply is not currently regulated but concerns about the practice have emerged. ${ }^{64}$

Yet these broad trends are not necessarily instructive for considering more discrete questions relating to the use of third-party funding in ISDS. The use of third-party funding in such cases is a separate issue that merits distinct treatment from the use of third-party funding in, for instance, corporate or tort disputes between private parties. Thus, rather than looking just at overall trends, it is important to examine the more specific questions of whether, to what extent, and why/why not governments permit third-party funding of domestic legal claims against themselves. Studies looking at third-party funding, however, generally do not look at the specific question of whether and to what extent the practice is regulated in the specific context of claims against the government. The next section looks at that issue, focusing on the specific case of third-party funding of claims against the US government.

\section{Third-party funded claims against Governments}

Governments often craft rules and mechanisms aiming to enable and encourage suits against their agencies, entities and officials. They do this in order to hold relevant actors and institutions accountable for harms and deter future wrongful conduct, and/or to provide compensation and other remedies to victims. ${ }^{65}$ This openness to suit, however, is also often accompanied by limits designed to serve other policy goals, such as avoiding overdeterrence, curbing frivolous and speculative claims, safeguarding public resources, and managing litigation costs and effectiveness. ${ }^{66}$ The rules can be complex, as policy questions relevant to the balance to be struck between supporting or restricting suits against the government are myriad and often competing. If, for example, governments want to affirmatively encourage efforts to sue their entities and/or officials for harms, they may consider such issues as the degree of fault (which may lie along a spectrum from strict liability, to negligence, to intentional violation of the law) and the nature of the harms (e.g., from harm to economic interests to violations of rights to life and liberty, or

\footnotetext{
${ }^{62}$ Pitkowitz (n 2) 18.

${ }^{63}$ ICCA-QM Report (n 1) 97. Burford Capital, 2017 Annual Report (2017) 11 ("Until 2017, both Hong Kong and Singapore had prohibited litigation finance (except in insolvency), and indeed any form of risk-based litigation activity, including lawyers taking risk on their own fees. However, following significant education and lobbying by Burford, both jurisdictions passed legislation in 2017 that enabled litigation finance for arbitration.")

${ }^{64}$ E.g. Pitkowitz (n 2) 3-23.

${ }^{65}$ One way these various objectives of legal claims (e.g., accountability, deterrence, compensation) can be advanced is to make it easier for complainants to pursue their cases. This can be done. for instance, through one-way fee-shifting. One-way fee shifting aims to "encourage[e] the maintenance of lawsuits by the beneficiaries of the fee shifting and at the same time both discourage[e] litigation and encourage[e] resolution of cases by the party who can only expect to pay fees, but not recover them. This effect motivates fee shifting provisions of the civil rights laws [in the United States] and other 'private attorneys general' statutes." Spurlock v. Sullivan [1992] 783 F. Supp. 474, 480-481.

${ }^{66}$ Palm Springs Medical Clinic, Inc. v. Desert Hospital [1986] 628 F. Supp. 454, 462-64 (discussing, for example, statutory revisions designed to protect municipalities from paralysis that could be triggered due to potential liability for treble damages under antitrust law, and other approaches for ensuring accountability).
} 
freedoms from nondiscrimination) when structuring rules on how broadly and actively to enable litigation. Additional considerations relate to different methods of encouraging suit, which can include relaxed standards of liability or burdens of proof, one-way or two-way fee-shifting rules, freedom to enter into contingency fee arrangements, liberal rules on subrogation, possibilities for damages claims and damage-multipliers, and third-party funding.

Each of those methods for encouraging suit has particular costs and benefits. Notably, however, third-party funding of claims against the government has, in some cases, been identified as being especially problematic. In the US, for instance, the congress adopted a relevant law largely banning such purchase and pursuit of legal claims. ${ }^{67}$ This longstanding federal statute, the Anti-Assignment Act, ${ }^{68}$ prohibits "a transfer or assignment of any part of a claim against the United States Government or of an interest in the claim," as well as "authorization to receive payment for any part of the claim." 69 There are exceptions, including that claims can be transferred after they have been determined to be valid and the amount owed has been decided (e.g., a court has determined that the government owns the plantiff $X$ amount), but the general rule remains in place.

The Anti-Assignment aims to serve several policy objectives:

first, to prevent persons of influence from buying up claims which might then be improperly urged upon Government officials; second, to prevent possible multiple payment of claims and avoid the necessity of the investigation of alleged assignments by permitting the Government to deal only with the original claimant; and third, to preserve for the Government defenses and counterclaims which might not be available against an assignee. ${ }^{70}$

The Anti-Assignment Act applies broadly across various causes of action, including to prohibit voluntary assignments of indirect takings claims ${ }^{71}$ and tort claims. ${ }^{72}$

This statute helps illustrates three key points. One is that even while governments may permit and even encourage suits against themselves in order to achieve certain policy objectives, they may nevertheless want to adopt rules governing the aims, interests and identities of potential claimants, and the identities of potential claimants, so as to avoid unintended and undesirable incentives to sue, and the problems that can arise when litigating against parties with whom the government had no direct dealing. Second, governments may want to expressly target third-party funding or other assignments of claims for regulation or bans due to the particular issues they raise. ${ }^{73}$ And third,

\footnotetext{
${ }^{67}$ Third-party funding is, however, permitted in various contexts involving private litigation; and tools like fee shifting, contingency fee arrangements, and damage multipliers are available in certain contexts to encourage particular types of claims against the government. Thus, the restriction on assignment of claims against the government is treated differently than assignment generally, or other efforts to enable lawsuits against the government.

6831 USC $\$ 3727$.

${ }^{69} 31$ USC $\$ 3727(a)$.

${ }^{70}$ Kingsbury v. United States [1977] 563 F.2d 1019, 1024.

${ }^{71}$ Bailey v. United States [2007] 78 Fed. Cl. 239, 267-68 (quoting United States v. Dow [1958] 357 U.S. 17, 20).

${ }^{72}$ See United States v. Shannon [1952] 342 U.S. 288, 289-90; Saint John Marine v. United States [1996] 92 F.3d 39, 46.

${ }^{73}$ Thus, while assignment of claims is prohibited, contingency fee arrangements may be allowed. See, e.g., The United States Department of Justice, Justice Manual, Civil Resource Manual 223 (Costs Recoverable from the United States) <https://www.justice.gov/jm/civil-resource-manual-223-costs-recoverable-united-states> accessed Mar. 20, 2019;
} 
even if some governments have decided that third-party funding should not be permitted for claims against the government at the domestic level, no such restrictions yet apply specifically to thirdparty funding in ISDS $;{ }^{74}$ this, in turn, means that the policy concerns behind such bans or other regulations, including concerns about motives for suit and undue influence of funders over the government, may not yet be adequately addressed in the context of ISDS.

\subsubsection{Investors' decisions to remain engaged in the host-country or exit}

Investment treaties are often justified as being useful tools for advancing economic development due to their role in attracting and retaining foreign investment including, in particular, FDI. FDI, a specific subcategory of international investment, is generally defined representing a long-term investment, and one over which the foreign investor exercises significant control. The long-term nature of FDI and the element of control are key features of FDI that present potential advantages for host states in terms of commitments of capital and transfers of technology.

Much analysis has been done to examine whether investment treaties actually attract FDI, with no clear or undisputed evidence that the presence of an investment treaty influences investors' decisions regarding whether or not to invest in an FDI project in a particular host state. ${ }^{75}$ Yet much less work has been done on the important question whether investment treaties and, more specifically, access to the powerful ISDS mechanism and associated remedies, influence investment decisions regarding whether or not to remain engaged in the host country and relevant investment project when circumstances or relations begin to deteriorate.

There are, however, reasons to suspect that ISDS and the possibility of expectation damages ISDS offers have a negative impact on investor retention and long-term investor-state relationships. While these issues arise even absent third-party funding, third-party funding may exacerbate concerns about these effects on investor-state relations.

Research on the behavior of contracting parties have suggested that, particularly in cases involving long-term incomplete deals - such as the types of contracts that often are used for extractive industry and long-term infrastructure projects - the health and durability of the deal can be served by legal frameworks that set forth and use "low-powered" enforcement mechanisms to encourage and strengthen commitments to ongoing good faith engagement, information sharing and cooperation between the parties. ${ }^{76}$ These kinds of low-powered enforcement mechanisms focus on

Pub. L. No. 94-559, 90 Stat. 2641 (codified as amended at 42 U.S.C. $\$ 1988$ (2000)); Mark R. Brown, 'A Primer on the Law of Attorney's Fees Under $\S 1988^{\prime}$ (2005) 37 (4) The Urban Lawyer 663, 665; Paul D. Reingold, 'Requiem for Section 1983' (2008) 3 Duke Journal of Constitutional Law and Public Policy 1, 1; Thomas A. Eaton \& Michael Wells, ‘Attorney's Fees, Nominal Damages, and Section 1983 Litigation' (2016) 24 William \& Mary Bill of Rights Journal 829.

${ }^{74}$ It is arguable, however, that if third-party funding of a claim against the government is not permitted under domestic law, that a third-party funding ISDS action against that government would be deemed inconsistent with public policy, providing an arguable ground for resisting enforcement under the New York Convention.

75 See n 59.

${ }^{76}$ See, e.g., Ronald Gilson, Charles F. Sabel and Robert E. Scott, 'Braiding: The Interaction of Formal and Informal Contracting in Theory, Practice, and Doctrine’ (2010) 110 Colum. L.Rev. 1377, 1387-1402; Adam B. Badawi, 'Relational Governance and Contract Damages: Evidence from Franchising' (2010) 7 J. Empirical Legal Studies 743; Erica L. Plambeck and Terry A. Taylor, 'Implications of Breach Remedy and Renegotiation Design for Innovation and Capacity’ (2007) 53 Management Science 1859. 
ensuring compliance with commitments to engage in relevant processes and in good faith. While damages may be awarded for breach, they are relatively limited in nature (to, e.g., reliance damages) as compared to "high-powered" sanctions for breach such as expectation damages. Such legal frameworks can help parties build the kind of relationship that allows their arrangement to survive over time and to help the parties to respond amicably to unforeseen circumstances. ${ }^{77}$

In contrast, legal frameworks that offer high-powered legal enforcement mechanisms and remedies such as expectation damages can discourage parties from engaging in the informal exchanges and problem solving necessary to build trust and maintain relationships. High-powered legal enforcement can "function[] as a 'first strike' nuclear weapon, allowing the nonbreacher to capture all contract gains and imposing all losses on the breacher." 78 Because a "single misstep can transform a surplus-generating cooperative enterprise into a zero sum game," "79 parties may not pursue (or be able to pursue without significant losses) otherwise desirable "actions - such as requests for mid-course adjustment of the contract - that invite a counterparty to reciprocate proportionally and informally...." 80 Powerful dispute settlement mechanisms and remedies, in short, risk crowding out cooperation, to the detriment of the contract's objectives and resilience.

This research has implications for ISDS claims, and third-party funding of those claims. Even without third-party funders, the availability of the high-powered enforcement mechanism of ISDS, and the ability to secure expectation damages representing the present value of potentially decades of future lost profits, may encourage investor claimants to litigate in ISDS, to seek early payouts, and to exit the project, rather than to continue to engage with host countries and remain invested in the project, particularly when relationships or circumstances become difficult. ${ }^{81}$ The prospect of forward-looking expectation damages - damages arbitral tribunals are reportedly ever more comfortable awarding, ${ }^{82}$ and that are relatively less commonly available under domestic law ${ }^{83}$ may, for instance, make it more attractive for investors in long-term infrastructure or extractives

${ }^{77}$ Gilson et al. (n 76).
${ }^{78}$ Ibid 1401-1402.
${ }^{79}$ Ibid.
${ }^{80}$ Ibid.
${ }^{81}$ See Alison E. Post, 'Home Court Advantage: Investor Type and Contractual Resilience in the Argentina Water

${ }^{81}$ See Alison E. Post, 'Home Court Advan
Sector' (2014) 42 Politics \& Society 107.

${ }^{82}$ Noah Rubins et al. (n 37) 200 ("[T]here has been a move away from backward-looking in favor of forward-looking (including market-based) methodologies reflecting increasing confidence among arbitrators that the rules of international law require full compensation based upon market indicators and that some degree of subjectivity and uncertainty, while inevitable, is not a bar to recovery...")

${ }^{83}$ See, e.g., David Gaukrodger, 'The Balance between Investor Protection and the Right to Regulate in Investment Treaties: A Scoping Paper' (2017) OECD Working Papers on International Investment 2017/02, 20-21. The examples given in the sentence in the text of circumstances in which ISDS may make it more attractive for investors to sue governments relate to changes in the legal framework or decisions taken outside the contract. In other words, they relate to legislative, regulatory or administrative actions or inactions that are not breaches of the contract, but may adversely affect the investor's recovery under the contract. Monetary damages, including expectation damages, for such legislative, regulatory or administrative actions are, as Gaukrodger notes, relatively rare under domestic law. Expectations damages, however, may be more likely to be available as a remedy for breach of contract. Nevertheless, as some have highlighted, there are policy questions about whether and when expectation damages against the government for breach of contract are in fact an appropriate remedy. See, e.g., Julie Roin, 'Public-Private Partnerships and Termination for Convenience Clauses: Time for a Mandate' (2013) 63 Emory L.J. 282 (noting the risk that expectation damages will keep governments from seeking to adjust the terms of investor-state contracts for even good faith public interest reasons and suggesting contracts limit the availability of such remedies). 
projects to adopt rigid positions protesting host state's attempts to change relevant parts of the legal or regulatory framework, or to adopt decisions adverse to the project (such as decisions to decline requests for tariff raises for public services, change the fiscal regime, or to impose environmental or other penalties). ${ }^{84}$ If the project faces difficulties, the investor may prefer to exercise its "nuclear option," exiting the deal and seeking future lost profits rather than accepting the changes or otherwise working towards a solution with the host-government.

The hypothesis that third-party funders may magnify these issues is based on two related factors: One is that third-party funders are attracted by the prospect of being able to recover a share of the claimant's (expectation) damages. This introduces into the investment relationship a new party with incentives for relatively near-term financial gains as opposed to revenues generated through longer-term engagement in the host country. ${ }^{85} \mathrm{~A}$ second factor is the likelihood, as discussed above, that the willingness and ability of third-party funders to fund these claims enables (more of) these claims to be brought. Indeed, the fact that third-party funders change investors' cost-benefit calculations regarding whether or not to sue their host states is a key benefit that third-party funders and proponents of third-party funding highlight - it facilitates claims by those otherwise unwilling or unable to bring them. Thus, by reducing the costs and increasing incentives to sue, and involving a new (and potentially controlling) actor whose interests are in suing and recovering rather than staying and engaging, third-party funding may increase the strains ISDS places on complex longterm deals, producing outcomes that seem to run counter to IIAs' aims of promoting "sticky", long-term investments benefitting the FDI investor as well as host states. ${ }^{86}$

\subsection{IMPACTS ON THE LAW AND OUTCOMES}

Much of the controversy around investment law, including whether it will result in host state liability for good faith public interest regulation of investment, arises not necessarily from the text

\footnotetext{
${ }^{84}$ This discussion links to the theory of the obsolescing bargain, which hypothesizes that once an investor has sunk capital in the host state, the investor's bargaining power vis-à-vis the state drops, and renders the investor vulnerable to the host state's efforts to readjust the terms of the deal in the host state's favor (or in the favor of particular government actors, entities). However, evidence seems to suggest that, at least in the context of long-term infrastructure deals, investors' bargaining power remains strong. See, e.g., J. Luis Guasch, 'Granting and Renegotiating Infrastructure Concessions: Doing it right' (2004) World Bank, WBI Development Studies < https://openknowledge.worldbank.org/handle/10986/15024> accessed April 29, 2019; J. Luis Guasch and Stéphane Straub, 'Infrastructure Concessions in Latin America' (October 2005) World Bank Policy Research Working Paper 3749. Gausch's research indicates that, rather than exploiting evolving power dynamics, government parties to publicprivate partnerships relating to infrastructure investments may more commonly be the victims of power shifts, often having to respond to investors' attempts to change the terms of the deal after it had been agreed. In one study of roughly 1000 concession contracts awarded in Latin America and the Caribbean between the mid-1980s and 2000, for instance, researchers found renegotiations occurred in 55\% of transportation concessions, and $74 \%$ of water and sanitation contracts. Strikingly, $57 \%$ of the transportation concession renegotiations were initiated by the investor alone ( $27 \%$ by the government alone and $16 \%$ by both the government and the operator); even more jarring, $66 \%$ of the water and sanitation contract renegotiations were initiated by the operator $(24 \%$ by the government and $10 \%$ by both the government and the operator). See also Lise Johnson, 'The Impact of Investment Treaties on Governance of Private Investment in Infrastructure' (2014) Robert Schuman Centre for Advanced Studies Research Paper No. RSCAS 2014/32.

${ }^{85}$ See, e.g., Rubins et al. (n 37) 200.

${ }^{86}$ In many cases the damages available under investment law exceed those available under domestic legal regimes, giving rise to a scenario in which ISDS can change the dynamics governing decisions regarding whether to stay and engage, or sue and leave.
} 
of the treaties, but from how the treaties have been interpreted by arbitral tribunals. Thus, one set of issues to evaluate when considering the advantages and disadvantages of third-party funding is its effects on the types of claims that are brought, development of the law, and outcomes of settlements. This section examines those issues.

\subsubsection{Impacts on the quality of cases: frivolous and marginal cases}

Those arguing that third-party funding will lead to more frivolous claims contend that the particular risk-return models in the disputes and the willingness and ability of funders to fund risky disputes, particularly when they can diversify increased risk with a portfolio of investments, ${ }^{87}$ will drive an increase in frivolous claims. Funders, on the contrary, state that it would make no sense to invest in claims that are likely to fail. Both positions may be accurate. The key issue is how "frivolous" claims are defined; and in the context of ISDS, that is a word that has yet to be given much meaning.

If a legal dispute involves application of a clear rule, such as a prohibition on driving over a certain speed, it will be relatively easy to identify whether a claim for speeding is or is not frivolous. But the more one moves away from a system governed by clear rules, to one governed by imprecise standards, the more difficult it will become to determine whether any claim or argument is indeed frivolous. On the rule-to-standard spectrum, the infamously broad and nebulous language in treaties mean that investment law is far along the "standard" side. ${ }^{88}$ What is fair? What is equitable? What is arbitrary? What is an indirect expropriation or, for that matter, a reasonable, investment-backed expectation? In light of the malleable and subjective nature of many of these terms and concepts, many positions are arguable and few facially without merit.

In addition to the challenges of identifying a frivolous claim that are raised by the standard-based nature of investment treaties, several structural forces in a system of ad hoc ISDS make it even less likely that frivolous claims are identified as such. One is that arbitrators are relatively independent of the states that are party to the underlying investment treaty, and may therefore consider themselves relatively free to depart from treaty parties' guidance and adopt their own interpretations of the underlying treaty language. ${ }^{89}$ This therefore can create a gap in practice between what states say the treaties mean and what tribunals interpret them to mean. Claimants can exploit that gap to pursue claims that appear frivolous to state treaty parties but may not be labeled as such by tribunals.

\footnotetext{
${ }^{87}$ See, e.g. ICCA-QM Report (n 1) 38 ("Structuring finance around multiple claims under either model usually involves some form of cross-collateralization, meaning that the funder's return is dependent upon the overall net financial performance of the portfolio as opposed to the outcome of each particular claim."); Burford, Beyond Litigation Finance (2016); IMF Bentham (n 30).

${ }^{88}$ Even modern treaties, which attempt to more carefully define what treaty obligations mean, still rely on vague standards as opposed to clear rules. The CETA, for example, attempts to clarify the "fair and equitable treatment" standard by saying that it prohibits "manifestly arbitrary" conduct (among other standards), which still retains the nature of a vague standard. CETA (n 2) Art. 8.10(2). On the subjective nature of "arbitrariness", see, e.g., Thomas J. Miles \& Cass R. Sunstein, 'The Real World of Arbitrariness' (2008) 75 U. Chi. L. Rev. 761

${ }^{89}$ See, e.g., Eric A. Posner and John C. Yoo, 'Judicial Independence in International Tribunals' (2005) 93 Cal. L. Rev. 1. ("Tribunals composed of independent members have a weaker incentive to serve those states' interests and are more likely to allow moral ideals, ideological imperatives, or the interests of other states to influence their judgments." Ibid 27).
} 
A second structural issue is that arbitrators, who are paid per case/hour rather than based on a set salary, may be incentivized to not close doors to certain claims or arguments, and instead give the impression that almost every claim is a colorable, non-frivolous one. In Apotex v. United States, ${ }^{90}$ for instance, the United States had argued to the tribunal that the NAFTA's most-favored nation provision did not permit the investor to import a more favorable FET obligation from the USJamaica BIT. The United States also highlighted that the other NAFTA parties shared that interpretation. ${ }^{91}$ But:

[r]ather than evaluate the NAFTA parties' positions or the legal significance of agreement among the three states on the issue, the tribunal proceeded to evaluate the claimants' claims under the US-Jamaica BIT as if the most-favored nation provision could in fact be used to import more favorable standards of protection. "[W]hether the NAFTA Parties [were] correct" in their interpretation that the most-favored nation provision could not play such a role would, according to the tribunal, "have to await the decision of another NAFTA tribunal." 92

The tribunal thus sent a signal to future claimants that they should feel free to test the same theory. And as others have commented, it is not uncommon for tribunals to provide these subtle messages of encouragement to future claimants. ${ }^{93}$

A third structural feature of ISDS that makes it difficult to label any claim frivolous is the fact that there is no system of precedent or appeal, meaning that even if the tribunal does reject an argument or case as failing or frivolous, that decision will not bar future attempts by claimants to raise the same legal argument.

Due, therefore, to the elusive nature of and apparently high bar applied to "frivolous" claims in investment law, it is useful to move beyond that label. Instead, the inquiry should be on whether third-party funding encourages marginal claims - claims that advance arguments about investment law that seek to stretch its reach in unintended and potentially undesirable directions.

But what, exactly, is meant in context when we refer to marginal claims? When governments explain the value of and need for investment treaties, they commonly do so using the relatively easy cases - the example of the investor that sunk costs in a long-term project in the host country

${ }^{90}$ Apotex Holdings Inc. and Apotex Inc. v. United States, Award, ICSID Case No. ARB(AF)12/1 (Aug. 25, 2014).

${ }^{91}$ Apotex v. United States, US Counter-Memorial and Objections to Jurisdiction, Dec. 14, 2012, paras 385-390.

92 Lise Johnson, 'New Weaknesses: Despite a major win, arbitration decisions in 2014 increased the US's exposure to litigation and liability' (CCSI 2015) 8-9 (quoting Apotex v. United States, para 9.71).

93 See, e.g., Robert Howse, 'Eli Lily v. Canada: A Pyrrhic Victory Against Big Pharma' (March 26, 2017) International Economic Law and Policy Blog <https://worldtradelaw.typepad.com/ielpblog/2017/03/eli-lilly-v-canada-a-pyrrhicvictory-against-big-pharma-.html> accessed April 29, 2019. Additionally, in dispute after dispute under the NAFTA, NAFTA parties have made submissions to the tribunal presenting their views of the NAFTA's FET provision and the relevance of the investor's legitimate expectations. Despite the briefing and the opportunity presented to tribunals to issue prospective claimants a clear statement about the law, tribunals often decline to decide the issue, enabling and potentially encouraging future claimants to try again. Every time a future claimant tries the same arguments, of course, a state incurs costs as it raises the same defenses. See Patrick Dumberry, 'The Emergence of a Consistent Case Law: How NAFTA Tribunals have Interpreted the Fair and Equitable Treatment Standard' (Oct. 30, 2013) Kluwer Arbitration Blog < http://arbitrationblog.kluwerarbitration.com/2013/10/30/the-emergence-of-a-consistent-case-lawhow-nafta-tribunals-have-interpreted-the-fair-and-equitable-treatment-standard/> accessed April 29, 2019. 
and, once there, was expropriated and appropriated without compensation by opportunistic domestic officials and left without a remedy by corrupt, biased or inept courts. They do not talk about the marginal cases. These are the cases in which, for example, a company sues after it is assessed higher taxes on windfall profits or charges for tax evasion; ${ }^{94}$ they are the cases in which the government in good faith imposed a ban or moratoria on extractive industry projects, or denied certain permits, based on public concerns that the environmental and social costs resulting from the project would outweigh the potential fiscal and economic benefits; ${ }^{95}$ and they are the cases where a government opts to stop giving investors tax incentives that drain public budgets and make little economic and policy sense. ${ }^{96}$ Many of these kinds of claims involve highly complex questions of public policies, preferences and competing rights and obligations, and are not cases in which the government was acting in bad faith or for discriminatory purposes to exploit foreign investors.

As Krzysztof Pelc recently found, it may be these marginal claims that are increasingly constituting the bulk of investment disputes. ${ }^{97}$ By "distinguish[ing] the 1,812 individual legal claims brought across 742 investment disputes, from 1993 to the present day": 98

[T]he investment regime has shifted in its primary purpose since its origins. Most disputes today are not over "sovereign theft" or direct takings, but over indirect expropriation. And most respondent countries are not rent-seeking regimes with low rule of law, but stable democracies with independent judiciaries. To put it in stark terms, the greatest portion of legal challenges in the investment regime today seeks monetary compensation for regulatory measures implemented by democracies. ${ }^{99}$

\footnotetext{
${ }^{94}$ E.g. Damien Charlotin, 'ICC Tribunal Finds in Favour of Energy Consortium in Billion Dollar Tax Dispute with Philippines' IAReporter (April 25, 2019) (award not public) (describing that a consortium of Chevron and Shell and a government-owned firm have prevailed in an investment dispute challenging a government tax monitoring agency (the Commission of Audit) determination that the consortium had underpaid billions in income taxes to the state). The consortium tried to use provisional measures to enjoin legal related proceedings before the Philippines Supreme Court. Luke Eric Peterson, 'Foreign Investor Asks Arbitrators to Enjoin Philippines Supreme Court Proceedings' IAReporter (Sept. 3, 2018).

${ }^{95}$ E.g. Pac Rim Cayman LLC v. Republic of El Salvador, Award, ICSID Case No. ARB/09/12 (Oct. 14, 2016); Lone Pine Resources Inc. v. Canada, ICSID Case No. UNCT/15/2; Eco Oro Minerals Corp. v. Republic of Colombia, ICSID Case No. ARB/16/41; Galway Gold Inc. v. Republic of Colombia, ICSID Case No. ARB/18/13; Red Eagle Exploration Limited v. Republic of Colombia, ICSID Case No. ARB/18/12; Cosigo Resources, Ltd., Cosigo Resources Sucursal Colombia, Tobie Mining and Energy, Inc. v. Republic of Colombia (not public); Infinito Gold v. Costa Rica (ICSID Case No. ARB/14/5); Bilcon of Delaware et al v. Government of Canada, Award on Jurisdiction and Liability, PCA Case No. 2009-04 (March 17, 2015) and Award on Damages (Jan. 10, 2019); TransCanada Corporation and TransCanada PipeLines Limited v. The United States of America, Order of the Secretary-General Taking Note of the Discontinuance of the Proceeding, ICSID Case No. ARB/16/21 (March 24, 2017).

${ }^{96}$ E.g. Spain faces nearly 40 investment claims arising out of, among related claims, changes made to incentives in its renewable energy sector. See e.g. S. Ripinsky, Damages Assessment in the Spanish Renewable Energy Arbitrations: First Awards and Alternative Compensation Approach Proposal (Nov. 29, 2018) Transnational Dispute Management. Romania also faces a claim arising out of changes to incentives schemes in its renewable energy sector. LSG Building Solutions and others v. Romania, ICSID Case No. ARB/18/19.

${ }^{97}$ Krzysztof J. Pelc, 'What Explains the Low Success Rate of Investor-State Disputes?' (2017) 71 Int'l Org. 559.

${ }^{98}$ Ibid 560.

${ }^{99}$ Ibid.
} 
These patterns may be independent of and unaffected by third-party funding; but third-party funding could be driving or magnifying these trends.

Analysis of the impact of third-party funding in the domestic context highlights what would be important to know in the ISDS context. Theoretical and empirical research done by David Abrams and Daniel Chen has concluded third-party funders have tended to take cases raising relatively novel issues. Looking at a sample of cases that a funder chose to fund and those the funder reviewed but ultimately chose not to support, the research finds that those selected for investment by the funder involved riskier claims that may have "otherwise failed due to legal uncertainty." 100 Abrams and Chen also compared third-party funders contingency fee lawyers, reasoning that as between the two, the third-party funders would be more likely to "work on cases that have a low chance of success." 101 As discussed in the next subsection, these findings support a position that third-party funding seems to be playing a role in pushing the boundaries of the law. ${ }^{102}$

\section{“Frivolous" claims and different implications for claimants and states}

While it may be undesirable for tribunals (and the precedent-less ISDS system) to leave doors quite open to claimants to raise and re-raise the same unsuccessful arguments, different considerations may arise with respect to states. Given the role of states as masters of their treaties, there may be good reasons for allowing them to continue to raise points notwithstanding their rejection by previous tribunals. For example, Argentina has stated repeatedly when defending cases involving minority, non-controlling shareholders that its treaties do not give this type of claimant the ability to seek relief for harms suffered by the company in which it held shares. ${ }^{103}$ While Argentina has routinely lost on this point, it has continued to make the case, asserting its view of the treaty to which it is a party and attempting to reassert its primacy in treaty interpretation and application. This practice by Argentina and other states is one way they can help ensure that treaties are interpreted consistently and in accordance with their object and purpose, and can also represent state practice that helps create and shape customary international law. If there were a system of precedent, or stronger signals by tribunals (e.g., through cost-awards) that arguments that had failed in the past were frivolous and should not be raised again, it may become more difficult for states to play these roles molding international law.

However desirable and important it may be for states to raise and re-raise defenses, doing so is costly. Defending ISDS arbitration has a high price tag - roughly US\$ 5 million by some

\footnotetext{
${ }^{100}$ Chen (n 50) 33; Abrams \& Chen (n 50) 1077.

101 Abrams \& Chen (n 50) 179.

102 Chen (n 50) 23.

${ }^{103}$ See, e.g., Urbaser v. Argentina, Decision on Jurisdiction, ICSID Case No. ARB/07/26 (December 19, 2012) 43, 204-54 (noting that Argentina had argued that shareholders can only bring claims for harms to rights/losses suffered as shareholders, and rejecting those arguments); Azurix v. Argentina, Decision on Annulment, ICSID Case No. ARB/01/12 (September 1, 2009) 85-130 (setting forth Argentina's arguments, the tribunal's rejection of them, and the annulment committee's decision to uphold the tribunal's decisions); BG Group v. Argentina, Final Award, UNCITRAL (December 24, 2007) 114 (noting that Argentina had raised the argument that shareholders could only bring claim for interference with their corporate rights, not "derivative" claims). For more information on public policy issues related to shareholder claims see David Gaukrodger, 'Investment Treaties and Shareholder Claims for Reflective Loss: Insights from Advanced Systems of Corporate Law’ (2014) OECD Working Papers on International Investment 2014/02.
} 
estimates ${ }^{104}$ - meaning that states may feel reluctant to spend time and money developing arguments with a losing track record, despite the broader implications of them not doing so. Even if a state's legal fees are shifted to an unsuccessful claimant, states frequently encounter difficulties collecting these awards. ${ }^{105}$

These considerations are different for an investor-claimant. As for a state, it takes monetary resources for an investor to raise losing arguments. But for investors, and unlike for respondent states, success on a previously unsuccessful argument can result in an actual win, a financial upside. The cost-benefit analysis of raising a wide range of claims, even if one or two are dismissed, may be worth the additional expense. And, with third-party funding, that calculation shifts even further as the financial downsides to the claimant are mitigated or eliminated. ${ }^{106}$ While states may ultimately be forced by practical, financial considerations to give up on pressing points and positions in treaty interpretation that have previously failed, investors and funders, who are able to shift and spread risks, may be motivated by the potential upside to continue to advance arguments that had been rejected in the past.

\subsubsection{Impacts on the substantive development of investment law}

In Abrams and Chen's studies of third-party funding Australia, not only did they find that it led to the filing of more cases generally, and more novel and uncertain cases in particular, but that decisions in third-party funded cases were particularly influential in developing the law, being reversed less and cited more than non-funded cases. ${ }^{107}$ The funded cases were therefore able to shape the ongoing development of the law to a greater extent than non-funded cases.

It is essential to ask whether the same thing is happening in investment treaty law. Are third-party funders having an impact on the substantive contours of the law by pursuing, and succeeding on, novel and marginal claims? If so, what are the implications for the content of that law and state obligations and liability under it?

Some research indicates that the involvement of a funder in ISDS cases will indeed make it more likely that claimants secure favorable decisions from tribunals. A 2014 study found that claimants prevailed in ISDS cases in which they had spent between 1.75 and 2 times more than the

\footnotetext{
${ }^{104}$ Behn \& Daza (n 17).

${ }^{105}$ E.g. Luke Eric Peterson, 'Frustrated by inability to collect on costs orders against foreign investors, Vietnam pushes for stricter 'security for costs' provisions in investment treaties', IAReporter (Oct. 27, 2018); Jarrod Hepburn, 'Analysis: Australia and Indonesia sign new FTA, including investment provisions on security for costs, third-party funding, dual citizens, and public health claims', IAReporter (March 5, 2019). See also Memorandum from Iván Zarak A., Acting Minister of Economy and Finance, Republic of Panama to Meg Kinnear, Secretary General, International Centre for Settlement of Investment Disputes, dated September 12, 2016 (stating that anonymous responses to a survey indicate that, among 35 respondent states that had been granted costs awards during the period under review, seventeen awards (49\%) had been paid in full, five awards (14\%) had been paid in part, and thirteen awards (37\%) had not been paid at all....among the twenty-two costs awards in favor of respondent states that had been paid either in full or in part, fourteen awards were paid voluntarily (64\%), two awards were paid pursuant to a settlement (9\%), and six awards were paid through enforcement $(27 \%)$ ).

106 Particularly as any sanction or downfall resulting from raising a "frivolous" claim is unlikely.

107 Chen (n 50) 42, 49; Abrams \& Chen (n 50) 1105-06.
} 
respondent. ${ }^{108}$ More recently, in a study of all known disputes filed between 1987 and 2015, Karen Remmer found that the availability of financial resources and access to sophisticated knowledge and information about the investment dispute process - each of which funders can contribute directly and through retention of top tier law firms - were important determinants of ISDS outcomes. ${ }^{109}$ Remmer concluded investors that are represented by the top tier international law firms with significant expertise in ISDS cases are more likely to win than those that are not funded by such firms; she similarly found that roughly $61 \%$ of those investors prevailed in the case or obtained a settlement. ${ }^{110}$ Whether or not respondent states had retained top tier law firms, however, did not have similarly strong impacts on outcomes. ${ }^{111}$ Compounding the uneven effects of access to funding and expertise, and as noted above, the near complete asymmetry in ISDS, means that access to funding and the knowledge, expertise, and access it can buy is not available to respondent states, at least not on anything resembling a scalable level. While defense-side funding is challenging in any legal system, it is all but precluded for respondent states in ISDS cases, likely making it even more difficult than it would be for investors to secure the legal and other expertise seemingly key to securing positive outcomes.

In addition to shifting outcomes in particular cases, third-party funding - and the increased chances of success it appears to bring (especially to investors) - can also shift outcomes in the law more systemically. Third-party funders depend on their ability to navigate investment law and ISDS. It is not a small step to conclude that their interest would also include shaping relevant norms in their favor, if and to the extent possible. ${ }^{112}$ Marc Galanter has described the advantages and objectives that repeat players, such as funders, have in legal systems, including: (1) opportunities to develop expertise and have ready access to specialists, (2) opportunities to develop facilitative informal relations with institutional incumbents, (3) the ability to adopt strategies calculated to maximize gain over a series of cases, even where this involves the risk of maximum loss in some cases (whereas parties only involved with a single case must always minimize the probability of maximum loss), (4) invest resources in shaping relevant rules over the long term, including by

\footnotetext{
${ }^{108}$ Tim Hart, 'Study of Damages in International Center for the Settlement of Investment Disputes Cases'(2014) 3 Transnational Dispute Management 11, 29 ("In cases where claimants won, we had party costs for both parties in eleven of those cases. In all eleven of those cases, the claimant spent more than the respondent. In this group of cases, the claimants spent 1.75 times the amount the respondents spent. If CSOB v. Slovak Republic is excluded, claimants outspent respondents by more than $2: 1 \ldots$ We do note however, that there is a bias in the underlying data as costs are generally reported most often in the awards in instances where the tribunal awarded costs and therefore cases with disproportionate costs spent by the winning party are more likely to be reported.")

${ }^{109}$ Karen Remmer, 'The Outcomes of Investment Treaty Arbitration: A Reassessment', in Yearbook on International Investment Law \& Policy 2015-16 (Johnson \& Sachs eds) (Oxford University Press 2018).

${ }^{110}$ Ibid 164-65 ("The data on legal resources reveal that both states and investors do so slightly more often than states. One of the world's top thirty-eight international law firms represents investors in 46 percent of ISDS cases, whereas states draw on the expertise of top firms in 38 percent of cases... The odds of a state prevailing in a dispute are 1.7 times higher if investors are not represented by a top firm. When investors engage prominent international law firms, 60.9 per cent of disputes conclude with either an investor win or settlement. Possibly by raising the perceived odds of investor victory, a prominent legal team may strengthen the incentives for states to reach compromises with claimants. No comparable evidence emerges for respondent states.")

${ }^{111}$ Ibid.

${ }^{112}$ Maya Steinitz, Whose Claim is this Anyway? Third Party Litigation Funding (2011) 95 Minn. L. Rev. 1268, 1314 (setting out why going to trial rather than settling may be in the strategic interest of funders: (1) generation and development of skills and subject-matter expertise, (2) reputation building (particularly for new funders), and (3) strategic rule-making and litigation until favorable decisions are obtained, while will favor parties with an ongoing interest.)
} 
such methods as lobbying (and because of the resources and expertise held by these kind of repeat players, they may be able lobby effectively), and (5) in some cases, be less concerned with the financial outcome in favor of an outcome that will favorably influence the outcome of future cases. ${ }^{113}$

In other words, the strategic funding of cases that push the boundaries and direction of investment law in ways that favor funders' interests is an expected and rational decision on the part of funders. ${ }^{114}$ For example, a funder recently dissatisfied with the tribunal's interpretation of an "implicit legality requirement" now seeks to overturn the denial of jurisdiction in the case. ${ }^{115}$ The annulment proceeding will come at a cost but will not, by itself, generate any financial recovery for the funder; nevertheless, it can be crucial for future success in that and other disputes that might otherwise close the door to claimants' claims on "illegality" grounds. ${ }^{116}$ While the funder's attempt to overturn this particular decision may be entirely motivated by its interest in the case at hand, it also seems quite reasonable to infer that this kind of "precedent" is unfavorable to a funder's longterm interest dependent on broader investor protections, which may also be a motivating factor in this context. While there is no de facto precedent, some arbitrators have expressed a sense of duty to seek to align their decisions with ones that had been issued in previous decisions; ${ }^{117}$ additionally, there are some cases, including annulment decisions, that appear to have been especially impactful on the development of the law. ${ }^{118}$

${ }^{113}$ Marc Galanter, 'Why the "Haves" Come Out Ahead: Speculations on the Limits of Legal Change' (1974) 9 Law \& Soc'y Rev. 95, 98-100.

${ }^{114}$ For example, in the case of Quasar de Valores SICAV S.A. et al. v. The Russian Federation, SCC Arbitration No. 24/2007, the funder, Group Menatep Limited, was a former majority shareholder in the Russian oil company, Yukos (not a commercial third-party funder) and there was no formal, written funding agreement. There was speculation that Menatep was funding the case in an effort to create favorable "precedent" that would be helpful in its future, much larger, shareholder dispute against Russia. Victoria Shannon Sahani, 'Revealing Not-for-Profit Third-Party Funders in Investment Arbitration' (March 1, 2017) Investment Claims. IMF Bentham states that "We will take the long-term view over the short-term, every time. This means preferring to maximize the value of our future cashflow over an immediate uplift in profitability." IMF Bentham (n 37) 4.

${ }^{115}$ See Damien Charlotin, 'Funder-Backed Investors Seek to Overturn Tribunal's "Black Swan" Finding that Investment Treaties Contain Implicit Legality Requirement; Two Tribunals Independently Reached Such a View Last Year,' IAReporter (March 20, 2019); Cortec Mining Kenya v. Kenya, Application for Annulment, ICSID Case No. ARB/15/29 (February 15, 2019).

${ }^{116}$ A separate tribunal had made a similar finding on the significance of "illegality" less than two weeks earlier. Ibid. ${ }^{117}$ See, e.g., Burlington Resources Inc. v. Ecuador, Decision on Liability, ICSID Case No. ARB/08/5 (December 14, 2012) para 187 ( "[T] he Tribunal believes that, subject to compelling contrary grounds, it has a duty to adopt solutions established in a series of consistent cases. It further believes that, subject to the specifics of a given treaty and of the circumstances of the actual case, it has a duty to seek to contribute to the harmonious development of investment law, and thereby to meet the legitimate expectations of the community of States and investors towards the certainty of the rule of law"). But see, e.g., Electrabel S.A. v. Hungary, Award, ICSID Case No. ARB/07/19 (November 15, 2015) para 224 ("This Tribunal is required to decide the arguments advanced by the Parties in this arbitration based on the evidence adduced by the Parties in these proceedings. It cannot be influenced therefore by the result of a different arbitration, where an investor's claim appears to have been formulated differently and decided on different arguments and evidence").

${ }^{118}$ See, e.g., Compañía de Aguas del Aconquia SA and Vivendi Universal v. Argentina, Decision on Annulment, ICSID Case No. ARB/97/3 (August 23, 2002) (holding that the tribunal had exceeded its authority by failing to take the claim due to a local litigation provision in the underlying concession). 
Moreover, portfolio funding permits risk diversification through the bundling of a long-shot case with favorable potential for rule change into a larger bundle of claims. ${ }^{119}$ In cases in which funders are granted the ability to influence or control decisions to settle claims or see them through arbitration, funders can ensure that such cases proceed through an award on the merits rather than settling. Because funders have no ethical obligations to the funded party, only to their shareholders, there are no ethical or regulatory hurdles to managing a claim in this way. ${ }^{120}$

In this context it is also important to recall that state parties to IIAs attempted to define the circumstances under which aggrieved individuals and entities may bring and succeed on claims against them in an international forum. While states have delegated to arbitral tribunals the role of interpreting and applying the substantive standards that govern their behavior to the specific factual circumstances at hand, it is the state party (and its treaty counterparty), who have granted the claimant a treaty-based and agreed right to arbitrate within the framework of protections granted, not beyond. ${ }^{121}$ Expansion of these protections in funder- (and claimant-) friendly ways thus threatens to distort the treaties, and cause their interpretation to move in directions that place undue restraints on government conduct.

\subsubsection{Impacts on decisions to settle claims}

While in some cases, such as when a funder is interested in influencing the development of the law, a funder may have an interest in seeing the claim through to an award. ${ }^{122}$ In other cases, a financial settlement may be a more attractive option. It is also possible that funders would seek for claimants to settle claims for reasons completely unrelated to the claim itself, such as the funder seeking to realize (or not) a profit during a particular time period, or to balance the overall risk (i.e. cases settling versus those continuing through the award phase) of a funder's investment portfolio.

A significant percentage of ISDS claims are reportedly settled between the parties prior to an award being issued. ${ }^{123}$ Given the lack of transparency around settlement generally, and third-party funding in particular, it is difficult to estimate how many funded cases settle (and whether they settle at different rates than non-funded cases). While settlements can be seen as positive outcomes, saving parties the time and expense of arbitration, in the context of ISDS, settlements also raise numerous public policy issues that cannot be ignored, including threats to principles of good governance (including government accountability), respect for the rule of law, transparency, and respect for citizens' rights and interests under domestic law and international human rights

\footnotetext{
${ }^{119}$ Burford Capital describes portfolio financing as "inherently flexible and ideally suited for defensive matters as well as claims, and for matters that would otherwise be less attractive for funding. Pricing is generally lower because risk is diversified." Burford, Beyond Litigation Finance (2016).

120 Steinitz (n 112) 1319.

${ }^{121}$ See e.g. Anthea Roberts, 'Triangular Treaties: The Extent and Limits of Investment Treaty Rights' (2015) 56 Harvard Int'l L. J. 2, 353 (setting forth a conceptualization of investment treaties as a triangular relationship where states, as the contracting parties, grant enforceable rights to investors, the third-party beneficiaries, to effectuate their own goals as states).

122 Steinitz (n 112) 1271.

${ }^{123}$ Behn and Daza find that $34 \%$ of all concluded cases have settled. Behn \& Daza (n 17). This number is certainly an underestimate. It does not capture the settlements of disputes that are not publicly known, does not reflect settlements that are negotiated prior to the filing of an ISDS claim, and does not reflect undisclosed settlements that result in the claimant officially withdrawing or failing to continue to pursue a claim.
} 
norms. ${ }^{124}$ With third-party funding, additional considerations arise. These include whether funders will impact settlement between the investor claimant and the government. A funder with control over settlement decisions could, for instance, prevent settlements for non-financial remedies that, even if designed to enable the relevant investment project to continue or restart, would not generate a monetary return for the funder. Additionally, the funder could prevent settlements under a certain amount.

Of course, every case is different and every funder is different, so, for instance, while some funders may never intervene with a funded party to promote a settlement, ${ }^{125}$ others may depend on cases settling for financial or easily monetized agreements. As one funder explained,

part of the secret of litigation investing is having a large, diversified portfolio so that we always have some cases going to trial, with the potential of high returns but the presence of binary risk of complete loss, while benefiting from the tendency of matters to settle and produce desirable returns from the majority of the portfolio without litigation risk. ${ }^{126}$

Another funder states that its investment managers "must be adept negotiators, because they are frequently required to negotiate... conditions of settlement and more." 127

Empirical work has considered whether third-party funding increases or decreases rates of settlement. For example, Chen's work in Australia finds that the introduction of third-party funding appears to increase settled outcomes. ${ }^{128}$

It would be important to understand these impacts in the context of ISDS. It may be, for example, that even if the funder does not have direct influence or control over decisions to settle, the asymmetric introduction of the third-party funder into a claim on the side of the claimant will shift bargaining power further in favor of the funded claimant and away from a respondent state with consequent impacts on willingness to settle and on settlement outcomes.

In terms of impacts on settlement outcomes, some analysis of third-party funding suggests that funders can help to achieve socially efficient dispute outcomes by facilitating a greater alignment of risk tolerance between the disputing parties. As Jonathan Molot explains when discussing thirdparty funding generally (i.e. not in the specific context of third-party funding in ISDS), ${ }^{129}$ disputing

\footnotetext{
${ }^{124}$ See Johnson \& Guven (n 40) (discussing public policy concerns surrounding the settlement of investment disputes and raising questions to consider in the context of reform of ISDS). While domestic legal systems often include mechanisms for public and/or judicial oversight of settlement agreements in order to protect the public interest when a settlement occurs, ISDS contains no such rules. Ibid (domestic legal mechanisms include, e.g.: statutory requirements that apply prior to the formation of a settlement agreement, such as rules requiring public notice and opportunity to comment on proposed settlements; rules permitting non-parties whose rights are impacted the right to intervene or object to settlements; requirements for judicial approval; doctrines that prevent enforcement of settlements that violate the law).

125 ICCA-QM Report (n 1) at 244 (Annex C).

${ }^{126}$ Burford, 2017 Annual Report (n 63) 4.

${ }^{127}$ IMF Bentham (n 30) 4 (the context is generic and does not make clear whether the statement includes or does not include ISDS claims).

${ }^{128}$ Chen (n 50) 49; Abrams \& Chen (n 50).

129 Jonathan Molot co-founded Burford Capital, a publicly-traded litigation finance provider, in 2009.
} 
parties settle to save the expenses of going to trial and to eliminate the risk of a worse-thanexpected trial outcome. ${ }^{130}$ To the extent two parties have roughly equal bargaining power, stand to gain equally from settling, and are well-educated on the merits and see eye-to-eye on the range of possible award outcomes, one would expect them to gravitate towards the expected meritsbased value of a suit in their settlement agreement, which may be preferable to a subsequent and potentially costly, lengthy, and misguided adjudicatory decision. ${ }^{131}$

Where, however, the parties have different risk tolerances, this imbalance in risk preferences may lead to an imbalance in bargaining power and to a settlement that departs dramatically from the mean expected jury award. A one-time, risk-averse party will be more fearful of the worst-case scenario than a repeat player because the risk-averse party cannot absorb and redistribute the costs imposed by an adverse ruling, unlike the repeat player who holds a diverse pool of litigation risk. For this reason, a one-time defendant worried about a catastrophic loss may agree to pay more than the mean expected damages award to eliminate that risk. Conversely, a one-time plaintiff worried about recovering nothing at all may agree to accept less. Where a lawsuit pits a one-time, risk-averse party against a repeat-player, riskneutral party, the imbalance may skew settlements significantly. The weaker party in these lawsuits may be willing to settle for an amount that departs dramatically from the mean damages award in order to eliminate the risk of a worst-case loss. ${ }^{132}$

Funders, which are "repeat players" in the legal market, can help level these asymmetries. They are knowledgeable, well-resourced, and are able to view each case from a risk-neutral perspective. When a weak party (or one-shotter) that is adverse to a stronger party (or repeat player) aligns with a funder, the alignment of that funder with the weaker party may help balance bargaining dynamics between the parties to the dispute and better ensure that settlement outcomes align with objective merits of the claim. ${ }^{133}$

But these dynamics - where the funder backs the weaker party or the one-shotter and helps level an otherwise unlevel playing fields in litigation against relatively strong adversaries or repeat players - do not seem to characterize typical ISDS cases where investors are frequently bargaining from positions of relative strength. Instead of reducing power asymmetries, the role of third-party funding in ISDS may instead serve to exacerbate them, increasing investors' bargaining strength relative to that of respondent states.

There are several reasons why investors may have greater strength and bargaining power through ISDS than states, power which stands to be strengthened even more by third-party funding. For one, most respondent states involved in ISDS proceedings are not repeat players engaged in a large number of ISDS claims. One study found that $60 \%$ of respondents have faced 5 or fewer claims. ${ }^{134}$ While some respondents have faced numerous cases, those cases may appear over a long period

\footnotetext{
130 Jonathan Molot, 'Litigation Finance: A Market Solution to a Procedural Problem' (2010) 99 Geo. L. J. $65,84$.

${ }^{131}$ Ibid.

132 Ibid.

${ }^{133}$ Steinitz (n 112) 1271.

${ }^{134}$ Behn \& Daza (n 17). Of 135 respondents in the study, 27 had faced 1 claim, 54 had faced between 2-5 claims, 25 had faced 6-9 claims, and 29 had faced 10 or more claims.
} 
of time, minimizing institutional learning that may occur. Additionally, the vast majority of ISDS respondents are revenue-constrained low-, lower-middle or upper-middle income counties. ${ }^{135}$

In contrast, a very high percentage of ISDS claimants are large and well-resourced multinational enterprises. ${ }^{136}$ One study found that the beneficiaries of ISDS-ordered financial transfers in favor of the claimant have "overwhelmingly been companies with more than US\$1 billion in annual revenue - especially extra-large companies with more than US\$10 billion - and individuals who have over US\$100 million in net wealth." ${ }^{137}$ In some cases, the annual revenue of a claimant dwarfs that of the respondent government. ${ }^{138}$ While claimants, like many respondents, tend to also have low levels of overall "repeat play", third-party funders, who can enable (and may require) the hiring of repeat-player, top-tier law firms and experts, and who also may exercise at least some control over the management of the claim, feature in recurring claimant-side positions.

Respondent states also face risks investors do not, which can further affect their willingness and ability to defend cases, and decisions regarding whether and on what terms to settle. States, which are on the receiving end of ISDS claims, are uniquely exposed to potential damage awards and reputational harms. While it is true that investor claimants may also face risks when bringing claims, namely risks of not recovering losses suffered (particularly in a context that lacks counterclaims), it is important to highlight that an investor's assessment of its risk of loss is not necessarily limited to its assessment of its ISDS case. This is because ISDS claims are not investors' only means of recourse. Rather, such claims may be pursued alongside potential recovery or relief pursuant to political risk insurance coverage, domestic law claims against the government,

\footnotetext{
${ }^{135}$ Ibid. Out of 135 respondents analyzed, 35 are World Bank Group classified low income, 42 classified as lowermiddle income, 40 classified as upper-middle income, and 35 classified as upper-income. Upper-income countries are also primarily sued by investors from other upper-income countries, whereas the claims against lower-income countries are primarily by upper-income country investors, but also include some low- or middle-income investors. Ibid. Developing states have also paid significantly more in damages than advanced economies. Kevin P. Gallagher \& Elen Shrestha, 'Investment Treaty Arbitration and Developing Countries: A Re-Appraisal' (May 2014) Global Development and Environment Institute Working Paper No. 11-01.

${ }^{136}$ See Daniel Behn, 'Legitimacy, Evolution, and Growth in Investment Treaty Arbitration: Empirically Evaluating the State-of-the Art' (2015) 46 Geo. J. Int'l L. 364.

${ }^{137}$ Gus Van Harten \& Pavel Malysheuski, 'Who has benefited financially from investment treaty arbitration? An evaluation of the size and wealth of claimants' (2016) Osgoode Hall Law School Legal Studies Research Paper Series 12(3), Research Paper No. 14, 1. This study found that companies with over US\$1 billion in annual revenue and individuals with over US\$100 million in net worth received about $94.5 \%$ of the aggregate ISDS-ordered financial transfers (93.5\% if pre-award interest is included). It was also evident that ISDS has delivered substantial monetary benefits to the ISDS legal industry.

${ }^{138}$ E.g. Karen Remmer notes that in Chevron Corporation and Texaco Petroleum Corporation v. The Republic of Ecuador, UNCITRAL, PCA Case No. 2009-23, Chevron's annual revenue exceeded US\$ 130 billion and Ecuador's less than US\$20 billion. Remmer (n 109) para 4.23. Chevron Corporation and Texaco Petroleum Corporation v. The Republic of Ecuador, UNCITRAL, PCA Case No. 2009-23. Of course, bringing a claim in ISDS is costly and unavailable to many small and medium size enterprises and individuals, so it is not necessarily surprising that large corporations and wealthy individuals are its primary users. However, it is also not clear whether small and medium size enterprises would have a significant number of claims at a value threshold that would make third-party funding feasible. See e.g. ICCA-QM Report (n 1) 252 (Annex C) ("The participants agreed that funders, of economic necessity and as a general matter, seek meritorious cases with claims large enough to merit the initial investment and ensure a reasonable return, which amount would generally translate to claims of at least US\$50 million.) Ibid 244 ("The group discussed the economics of third-party funding, noting that it costs about US\$5 million to finance an ISDS claim, so damages must be at least US\$30-40 million in order to make the claim financially feasible for funders.")
} 
diplomatic pressure, ${ }^{139}$ or contract-based claims. Thus, the basic one-way structure of ISDS claims, and the relationship of ISDS with other fora, mean that the ISDS mechanism systemically exposes respondent states to greater risks of loss than investor claimants. Third-party funding, by enabling claimants to avoid or reduce the cost and risk of litigation, exacerbates this asymmetry.

Risk-tolerance of respondents is also reduced relative to that of investors by the fact that investment law is a standard- rather than rule-based legal system. ${ }^{140}$ Rules - e.g., prohibitions on driving over a certain speed - are precise and it is fairly easy to determine when such a rule has been violated. The more a legal system moves away from one governed by clear rules to one governed by imprecise standards, the more costs of compliance grow. ${ }^{141}$ In standards-based legal systems the costs of compliance are largely born by those who seek to conform their behavior to standard-based law. ${ }^{142}$ In situations where states are unclear of how law will be applied to fact, they may be willing to settle for an amount that may depart from an objectively anticipated damages award in order to eliminate the risk of a worst-case scenario. ${ }^{143}$

Overall, and in contrast to how it may work in other contexts, the injection of a third-party funder into a claim on the side of the ISDS claimant does not seem to level the playing field, or create efficiencies in settlement outcomes. Rather, investor access to third-party funding, and the deep experience, expertise, insider information and resources that are provided by funders, may instead exacerbate the unbalanced power dynamics that already exist between many investors and states which see investors approaching claims from positions of relative power advantage. ${ }^{144}$ In light of these factors, state may rationally decide to settle rather than contest a claim even when the claim is based on questionable legal grounds or when the state has a strong defense. ${ }^{145}$ Third-party

${ }^{139}$ Although the ICSID Convention and some bilateral investment treaties may constrain investors' ability to secure diplomatic protection while also pursuing ISDS claims, it is important to highlight that a significant percentage of ISDS claims are not ICSID claims, and that investors have also pursued ISDS claims against host governments using Home Country A's investment treaty with the host state while securing diplomatic support from Country B. See, e.g., South American Silver v. Bolivia, Award, PCA Case No. 2013-15 (August 30, 2018), and Dissenting Opinion of Osvaldo Cesar Guglielmino (August 30, 2018) (indicating that the claimant had sought diplomatic protection from Canada while bringing the case under the BIT between Bolivia and the United Kingdom); ADC Affiliate v. Hungary, Award, ICSID Case No. ARB/03/16 (October 2, 2006) paras 361-62 (noting that the claimants' shareholders had sought help from the Canadian government while the claimants pursued relief under the Cyprus-Hungary BIT).

140 Shyamkrishna Balganesh sets forth these arguments in the context of copyright law and the use of third-party funding in that context. Shyamkrishna Balganesh, 'Essay: Copyright Infringement Markets' (2013) 113 Colum. L. Rev. 2277.

${ }^{141}$ While standards-based systems can become more rule-like when ex-post contextualization can help to inform expectations and shape behavior, ISDS does not have the elements required to permit this contextualization to occur. In ISDS, vague legal standards are interpreted and applied by ad hoc arbitrators who are not bound by precedent and whose decisions are not subject to appeal.

142 Balganesh (n 140) 2296 (These costs typically manifest by requiring increased time and effort to understand the law and the behavior that it condones, or alternatively, condemns; by hiring or training legal advisors who can understand and advise (in)action necessary for compliance; and/or through a comprehensive system of adjudication that can contextualize and fill in the practical content of standards ex-post.)

${ }^{143}$ See e.g. Molot (n 130) 84.

${ }^{144}$ While not the subject of this paper, in cases where claimants had a choice to bring a claim based on the same alleged wrong in a different forum, the claimant has presumably assessed its options and preferred ISDS over that forum. See e.g. Johnson, Sachs \& Sachs (n 53).

${ }^{145}$ Notably, settlement offers need not be monetary, but could be in the form of the state relaxing the regulatory environment in favor of the investor's interests (which may not be in the interest of society at large). E.g. Dow AgroSciences v. Canada (n 26) (describing how the Canadian province of Quebec settled a claim brought by a US 
funding can thus shift evolving power dynamics and settlement outcomes in favor of an investor and away from the state in cases where such dynamics may already be significantly skewed.

\subsection{IMPACTS ON RESPONDENT STATES AND THEIR GOVERNANCE OF INVESTMENT}

\subsubsection{Impacts on state conduct: regulatory chill and overdeterrence}

Governments, in order to fulfill their range of responsibilities to a wide variety of individuals and groups, need policy space and authority to enact, implement, revise, refine, and enforce their laws, policies, and practices in order to achieve public interest objectives and to react to changing circumstances, evidence, needs, and priorities. ${ }^{146}$ This policy space can be of particular importance for governments whose legal frameworks are still evolving and developing to reflect best international practice. Of course, policy space is not, and should not be, unlimited. It is constrained by, for instance, contract, domestic constitutional and administrative law, and by customary and treaty law on a range of issues including human rights. Thus, investment treaties are far from unique in constraining government powers and are not here criticized on those grounds per se. What is important is to understand the nature of constraints placed on states by investment treaties, how and why they go beyond those imposed through other sources of law, and the extent to which they may overdeter, by unduly discouraging (or requiring compensation for) good faith actions taken by governments in the public interest to achieve economic, social and environmental aims. ${ }^{147}$

The availability of third-party funding in ISDS has the effect of facilitating and encouraging suits against governments because a profit seeking industry is able to generate returns by taking a financial interest in the outcome of claims and has incentive to ensure qualifying ISDS cases are brought (and that the law is developed in the funding industry's favor) . Controversially, in many cases third-party funders may be profiting from the financing of claims against governments that have engaged in good faith conduct taken in the public interest. It is unclear that, in light of the object and purpose of IIAs, the ISDS system should affirmatively encourage such suits by maintaining permissive rules on third-party funding.

In this context, it is important to ask what impacts on government conduct may arise if we consider that third-party funding may increase the number of cases filed, may also lead to the filing of more marginal cases, and/or may affect outcomes of awards and settlements. As is briefly discussed below, in light of those and other issues, there are several reasons to suspect that third-party funding may exacerbate current concerns about undue regulatory chill

Because investment law is a standards-based legal system, it can be extremely difficult for governments, in particular, to understand which claims have merit and what applicable damages

chemical manufacturer relating to a ban on certain cosmetic pesticides not through monetary compensation, but by issuing a statement indicating that the chemical in question does not pose an unacceptable risk to human health or the environment when instructions on the label are followed.)

146 Johnson et al. (n 10) 11-13 (this section summarizes the section on "reduced policy space" in that paper).

${ }^{147}$ Ibid 11-12 (looking at indirect expropriation and the evolution and application of the right to property to demonstrate how investment law as interpreted through ISDS decisions has tended to disfavor change and reallocation and instead emphasizes the importance of ensuring that investors and their investments are able to enjoy stability in legal rules, even when governments are regulating in good faith, for the public interest, and in compliance with domestic law). 
may be. The resulting uncertainty in the law, exacerbated by the inconsistency of its application and the absence of a correcting mechanism, makes it extremely challenging and costly for governments to assess the likelihood that their conduct will conflict with treaty standards. Thus, such uncertainty and corresponding reputational and (highly enforceable) financial costs could discourage states from defending measures contested by investors through to awards and potential post-award phases. ${ }^{148}$

Some governments may be more sensitive to regulatory chill than others. For example, those with limited resources to fund a robust defense and any potential liabilities, those that are more sensitive to any reputational costs, ${ }^{149}$ or those that are dependent on other countries for development assistance, economic regulations or diplomatic support, may be less willing to contest claims,. ${ }^{150}$ In such cases, investors may hold a relatively strong upper-hand in settlement negotiations, when the threat of an ISDS case looms. The presence of a third-party funder backing the suit may further tilt bargaining power in the claimant's favor and induce a settlement that, even if not causing the government to abandon the measure, increases its cost of maintaining it, which may deter the government from taking similar action in the future. A government, for instance, may not back down on its decision to halt a mining project in light of social and environmental concerns; but the financial cost of a resulting ISDS settlement may discourage the government from similarly responding to environmental and social issues when they arise around other proposed projects.

Additionally, even if a government decides not to settle and to pursue its case, the presence of a third-party funder, as noted above, may make it more likely that the government will lose and have to pay for adopting and/or maintaining the challenged measure. That, in turn, make it more costly - and potentially prohibitively costly - for the government to keep the measure in force postdispute, or to adopt similar measures in the future.

Finally, impacts of third-party funding on government conduct and issues of regulatory chill may be more systemic. The overriding objective for funders is, in short, to maximize returns on investment in ISDS cases. There is no evidence that they filter claims based on the nature of the conduct challenged - e.g., by deciding not to pursue claims that arise out of complex policy decisions and good faith conduct taken for legitimate public purposes. Thus, third-party funders raise the risks of ISDS claims even for governments considering adopting public interest measures; and the defense costs, reputational harms, and potential liability associated with those claims may deter governments from taking relevant action in the first place. One law firm notes, for example, that "for every investor-State case that goes through to completion, there are several instances where companies have used IIAs as leverage to negotiate with the host government and cause it to change its behavior more quickly and less expensively." 151 Similarly, to the extent that third-party

\footnotetext{
148 Jonathan Bonnitcha, 'Substantive Protection under Investment Treaties: A Legal and Economic Analysis' (Cambridge University Press 2014) 127 (citing Kyla Tienharra, 'Regulatory Chill and the Threat of Arbitration: A View from Political Science' in Chester Brown and Kate Miles (eds) Evolution in Investment Treaty Law and Arbitration (Cambridge University Press 2011) 606, 615.

149 The mere filing of an ISDS claim may decrease a respondent state's attractiveness as a site for FDI, and if the state loses, the decrease may even be more significant. Allee \& Peinhart (n 33).

150 Bonnitcha (n 148) 118-27.

${ }^{151}$ Crowell \& Moring, 'How Mining Companies Can Mitigate Risks and Protect their Investments, Part I: International Investment Agreements' (2014) <https://www.crowell.com/NewsEvents/AlertsNewsletters/all/How-Mining-
} 
funders are actually seeking to and effective in developing the law in funder- and claimant-friendly ways, that can have the eventual effect of narrowing the circumstances when governments can feel comfortable that their considered conduct will not trigger claims.

This issues regarding regulatory chill and the overdeterrence of government behavior are already identified concerns about the ISDS system more generally. ${ }^{152}$ But the presence of third-party funding appears to exacerbate the concerns. It allows more speculative claims to be advanced as it eliminates risk to the claimant of advancing them; it signals to governments that such claimants have resources available to mount a well-prepared claim, and to see that claim through an award and potential post-award processes, including resubmission of the claim in a new proceeding; and it can shift outcomes and the law in ways that are favorable to funders (and claimants), but blind to more systemic policy questions such as when and how legal systems should require governments to pay for, and enable private actors to profit from, different types of "misconduct" of government actors and entities.

\subsubsection{Impacts on governance of certain types of investments}

The implications of third-party funding and ISDS claims for governments and governance are not necessarily the same across sectors and industries. As was noted above, for instance, investments in the extractive industries and long-term infrastructure projects are apparently linked to relatively heightened risks of claims, and heightened damage awards, and may be particularly attractive to third-party funders due to their large potential payouts. ${ }^{153}$

Additionally, the impacts of investments in these industries present potentially transformative opportunities but also corresponding threats for host countries (and investors), and the extent to which gains are maximized and harms avoided is due in large part to the legal and policy frameworks in place to manage the projects. Thus, it is exceedingly important to understand how ISDS and third-party funding of ISDS claims can impact governance of projects, including governments' willingness and ability to regulate, and the costs governments may incur in adopting and maintaining regulations that are challenged by investors and seen as giving rise to viable claims by funders. ISDS claims in these sectors often stem from regulations or actions taken by a government to respond to concerns about potential negative social, economic and environmental effects of projects, including concerns raised by communities surrounding extractive industry projects, or users of services provided by infrastructure investors. ${ }^{154}$ To the extent that funders are funding more of these extremely socially complicated kinds of cases, and increasing the resources and interests dedicated to protecting capital in the face of competing claims, there may be

\footnotetext{
Companies-Can-Mitigate-Risks-and-Protect-their-Investments-Part-I-International-Investment-Agreements> accessed Mar. 20, 2019.

${ }^{152}$ UNCITRAL, Report of Working Group III (n 2) paras 36, 37.

153 ICSID, 'The ICSID Caseload - Statistics' (Issue 2018-2) (2018) 28 (including Oil, Gas \& Mining (21\%); Information \& Communication (5\%); Transportation (2\%); Construction (11\%); Water, Sanitation \& Flood Protection (4\%); Electric Power \& Other Energy (16\%). See Hart (n 108) 8-10 (including a ranking of top 30 claims/damages awards as of 2014).

${ }^{154}$ See, e.g., Lorenzo Cotula \& Mika Schröder, 'Community Perspectives in Investor-State Arbitration' (IIED, 2017).
} 
undesirable systemic implications on the broader set of voices and interests impacted by investment treaties, and governments' willingness and ability to respond to them. ${ }^{155}$

\subsubsection{Impacts on certain respondent states}

Not all states face the same exposure to and challenges from third-party funding. Anecdotal evidence suggests that third-party funders have little or no interest in funding claims against states that have substantial resources and talent to present a strong defense to an ISDS claim, or against states that are highly impoverished and will be unable to pay even a small fraction of an eventual award. ${ }^{156}$ This suggests that it may be middle-income countries, and countries that are relative novices at handling ISDS cases, that are particularly attractive targets. Additionally, countries that are reliant upon resource extraction as a development strategy, or private investment in infrastructure to compensate for limited public budgets and thin capital markets, may figure prominently on funders' radars, especially if the regulatory frameworks governing either are relatively nascent, changing, and/or a bubbling source of controversy. As and to the extent these countries' legal frameworks evolve to, for example, better capture tax revenue from natural resource projects, ${ }^{157}$ more meaningfully recognize indigenous communities' rights to free prior and informed consent, ${ }^{158}$ ratchet up environmental protections or otherwise address environmental issues or concerns, ${ }^{159}$ or resist investors' requests to increase tariffs or reduce service obligations in infrastructure projects, ${ }^{160}$ they risk being the object of an ISDS claim under the substantive standards contained in most IIAs.

${ }^{155}$ Kyla Tienhaara, 'Regulatory Chill in a Warming World: The Threat to Climate Policy Posed by Investor-State Dispute Settlement' (2018) 7 TEL 729; Julia Brown, 'International Investment Agreements: Regulatory Chill in the Face of Litigious Heat?' 3(1) West. J. Legal Stud.; Gus van Harten \& Dayna Nadine Scott, 'Investment Treaties and Internal Vetting of Regulatory Proposals: A Case Study from Canada' (2016) 7 J. Int'l Disp. Settlement 92.

${ }^{156}$ At the Columbia University roundtable, one participant stated that funders are unlikely to fund ISDS claims against respondent states that are likely to prevail, such as the United States or Sweden, or against deeply impoverished states because of enforcement concerns, or otherwise. ICCA-QM Report (n 1) 244 (Annex C).

${ }^{157}$ See, e.g., ConocoPhillips and Perenco v. Vietnam (not public); Luke Eric Peterson, 'Vietnam faces unusual BIT arbitration, with seller and purchaser of assets teaming up to file a joint claim in face of country's threat to impose a capital gains tax' IAReporter (Apr. 3, 2018) (describing a claim brought by two subsidiaries of ConocoPhillips and Perenco, respectively, regarding Vietnam's intention to impose a form of capital gains tax on the sale of an investment). See also George Turner, 'ConocoPhillips and Perenco try to stop $£ 140 \mathrm{~m}$ levy from sale of oilfields in key case for tax avoidance for multinationals' The Guardian (Aug. 15, 2018).

${ }^{158}$ See, e.g., Bear Creek Mining v. Peru, Award, ICSID Case No. ARB/14/21 (November 30, 2017).

${ }^{159}$ Pending cases include, e.g., Agro EcoEnergy Tanzania Limited, Bagamoyo EcoEnergy Limited, EcoDevelopment in Europe AB, EcoEnergy Africa AB v. United Republic of Tanzania, ICSID Case No. ARB/17/33; Kingsgate Consolidated Ltd. v. The Kingdom of Thailand (not public); Lone Pine Resources Inc. v. Canada, ICSID Case No. UNCT/15/2; Eco Oro Minerals Corp. v. Republic of Colombia, ICSID Case No. ARB/16/41; Galway Gold Inc. v. Republic of Colombia, ICSID Case No. ARB/18/13; Red Eagle Exploration Limited v. Republic of Colombia, ICSID Case No. ARB/18/12; Cosigo Resources, Ltd., Cosigo Resources Sucursal Colombia, Tobie Mining and Energy, Inc. v. Republic of Colombia (not public); Infinito Gold v. Costa Rica (ICSID Case No. ARB/14/5). Decisions in favor of claimant (or settled) include, e.g., Bilcon of Delaware et al v. Government of Canada, Award on Jurisdiction and Liability, PCA Case No. 2009-04 (March 17, 2015) and Award on Damages (Jan. 10, 2019); TransCanada Corporation and TransCanada PipeLines Limited v. The United States of America, Order of the Secretary-General Taking Note of the Discontinuance of the Proceeding, ICSID Case No. ARB/16/21 (March 24, 2017). Decisions in favor of state (including on jurisdiction) include, e.g., The Renco Group, Inc. v. Republic of Peru, Final Award, ICSID Case No. UNCT/13/ (Nov. 9, 2016); Pac Rim Cayman LLC v. Republic of El Salvador, Final Award, ICSID Case No. ARB/09/12 (Oct. 14, 2016).

160 TECO Guatemala Holdngs v. Guatemala, Award, ICSID Case No. ARB/10/23, (December 19, 2013). (Guatemala's subsequent application to annul was unsuccessful; the claimant was successful in a request for partial 
If funders are in fact more likely to fund claims against some governments than others, this has several important implications. It may result in patterns whereby some countries - countries that have faced or are likely to face third-party-funder supported claims - are more familiar with the impacts of such funding and more interested than others in supporting restraints on such litigation finance practices. (Additionally, if funders and the funding industry are concentrated in certain states, this may result in patterns whereby the funders' home countries resist regulation). To the extent that bilateral or multilateral solutions are necessary to address concerns about third-party funding, the unequal distribution of third-party funding's costs and benefits across treaty parties may mean that the practice will continue notwithstanding the objections of particularly exposed and negatively impacted states.

Additionally, to the extent that the presence of funding has an impact on ISDS decisions and settlement outcomes, disparate patterns of funder engagement may cause different states to have disparate experiences with investment law and ISDS that are not due to the contents of underlying treaties or the strength of the merits, but the resources, knowledge and networks of litigating parties. ${ }^{161}$ This, in turn, may magnify questions about the overall legitimacy of the system.

These dynamics overlay similar dynamics that arise with ISDS more generally. While the treaties are, on paper, reciprocal between treaty parties, investment flows between treaty parties tend to still be largely one-way, meaning that treaties and ISDS are asymmetrical in practice, with some treaty parties more routinely or exclusively on the defense than others. The international investment law regime already has a lopsided impact on states in the developing world, who are the primary targets of investor claims (relative to GDP or government budgets) and who have already paid significantly more in damages than advanced economies. ${ }^{162}$ If third-party funding skews toward claims against countries or groups of countries already facing a disproportionate share of ISDS cases, this may exacerbate ISDS's asymmetrical effects.

Given these issues, it is important to understand if certain countries or certain country profiles, such as developing and middle-income countries, or countries with FDI concentrated in particular sectors and activities, are the primary targets of funded claims. If funders are fueling more cases against certain groups respondent states, the systemic impacts on sustainable development and equality before the law could be severe.

\section{Policy Options}

Whatever its role or value in other legal frameworks or fora, third-party funding in ISDS is unique. Arguments about the "need" for third-party funding in ISDS to ensure "access to justice" both seem to overstate the "need" for this particular form of support and the role of ISDS in ensuring "access to justice". Moreover, the asymmetrical nature of ISDS fundamentally distorts the ability

annulment, Decision on Annulment, April 5, 2016); but see Iberdrola v. Guatemala, Award, ICSID Case No. ARB/09/5 (August 17, 2012) (Iberdrola's subsequent application for annulment was unsuccessful) and Decision on Annulment (January 13, 2015).

${ }^{161}$ See discussion supra, Section 3.2.3 'Impacts on Decisions to Settle Claims'.

162 Gallagher \& Shrestha (n 135). This is one reason Frank Garcia characterizes third-party funding in ISDS as deliberately and systemically exploitative. Frank J. Garcia, 'Third-Party Funding as Exploitation of the Investment Treaty System' (2018) 59 B.C.L. Rev. 2911. 
of third-party funding to help level playing fields and create market efficiencies. Instead, thirdparty funding may exacerbate problems with underlying investment standards and the ISDS mechanism, and introduces a new actor into the ISDS system with its own incentives for challenging, inter alia, the type of robust government regulation that is needed to advance sustainable development objectives. In short, the value of third-party funding to actors other than funders and some claimants has not yet been made clear, while the risks are increasingly apparent.

Importantly, various states, arbitral institutions, and other international organizations, such as UNCITRAL's Working Group III, are now analyzing third-party funding in ISDS, and considering what, if anything, should and can be done about it. However, a failure to use these processes to adequately identify and grapple with the myriad issues raised by the practice will allow for continued expansion of funders and funding and make future regulatory action even more challenging.

It is sometimes asserted (particularly by funders) that regulation is not necessary; either existing regulations on claimants and lawyers, as well as those generally placed on funders who are publicly traded, or banking entities, are sufficient. ${ }^{163}$ Or simply that funders self-regulate as an industry. ${ }^{164}$ With respect to the first form, regulation of financial and banking entities does not address the public policy concerns from the perspectives set forth in this paper. With respect to the second form, it is difficult to envision how industry self-regulation would be systemically possible when incentives for profit-seeking behavior are so strong and particularly as more and more funders enter the field and are in competition for these profits. Given that levels of transparency regarding funding terms and funded ISDS cases are particularly low it would seemingly be impossible, even within the industry, to know when third-party funders are violating any kind of hypothetical selfregulation in the first place. Moreover, a key aspect of effective regulation is, ultimately, the threat or imposition of sanctions for wrongdoing, which does not currently exist in the third-party funding sector. Presumably, then, notions of self-regulation mean that the market self-regulates; no funder can survive if it does not make a profit, and that means choosing strong, viable cases. Putting aside the fact that financial success and ethical regulation are not the same thing (and indeed, the former often comes at the expense of the latter), funders that ultimately do not earn a sufficient financial return to stay in business can inflict harm in specific cases in the interim. This is not an insignificant concern, particularly for the respondent states that may be most impacted by funding arrangements.

There are thus two options for policy makers: ban it or regulate it.

\subsection{BAN THIRD-PARTY FUNDING IN FULL OR IN PART}

Calls for third-party funding to be banned in its entirety in ISDS are primarily based on the recognition that it offers very few, if any, benefits but introduces serious and systemic costs to states and other stakeholders. ${ }^{165}$ Proponents of a ban often recognize that whatever its merits in

163 E.g. Letter from Burford to Senators Charles E. Grassley and John Cornyn (September 25, 2015) <http://www.burfordcapital.com/blog/burford-submits-response-to-us-senators/> accessed March 18, 2019).

164 Ibid.

${ }^{165}$ Frank J. Garcia, 'The Case Against Third-Party Funding in Investment Arbitration' (July 30, 2018) Investment Treaty News <https://www.iisd.org/itn/2018/07/30/the-case-against-third-party-funding-in-investment-arbitrationfrank-garcia/> accessed April 29, 2019; Frank Garcia and Kirrin Hough, 'Third Party Funding in International 
traditional litigation and commercial arbitration, third-party funding has no place in investment arbitration, at least as long as long as IIAs and ISDS continue to possess certain features, including extreme asymmetry, substantive reliance on standards as opposed to clear rules, relatively easily jurisdictional access to ISDS, and a general failure to sanction frivolous claims at either the merits or damages phase. Frank Garcia has, for example, asserted that as long as third-party funders are operating within a system that is as unbalanced as ISDS, where states have no substantive rights under the treaties, claimants have a direct voice in the selection of arbitrators, and there is no right of appeal, third-party funding is "to put it bluntly, an exploitation... defined as a form of "unfair advantage-taking." "166 Pursuant to Garcia's arguments, allowing speculative finance to take a stake in the outcome of ISDS cases, to have a voice in or influence over which arbitrators are chosen, and when and for how much cases will settle, deliberately exploits deep-rooted flaws in the investment treaty system for the benefit of capital and at the expense of governments, taxpayers and citizens. ${ }^{167}$

States, too, have called for a ban on third-party funding in ISDS. For example, several states in the context of UNCITRAL's Working Group III on ISDS reform have suggested that a complete ban may be necessary to address the broad concerns caused by third-party funding in ISDS. ${ }^{168}$ Argentina and the United Arab Emirates have gone one step further and actually included a ban in

Investor-State Arbitration' $\quad$ Nov. 1, 2018) ASIL $\quad$ Insights
https://www.asil.org/insights/volume/22/issue/16/third-party-funding-international-investor-state-arbitration
accessed April 29, 2019.
166 Garcia (n 165).
167 The fact that in ISDS the respondent state taxpayers alone are the residual risk-bearers, as opposed to third-party funding in the commercial arbitration context where both sides' shareholders bear the residual risk of adverse judgments, is another reason that third-party funding in ISDS must be distinguished from other contexts. Garcia (n 165).

168 See e.g. Working Group III 35 th Session, Audio recordings (April 25, 2018) <https://icms.unov.org/CarbonWeb/public/uncitral/speakerslog/a2ad492b-22e9-497c-93c8-4be3130e9978> accessed April 29, 2019. Nigeria stated that third-party funding "[r]aises a moral, ethical and public policy issues why a total stranger who has suffered no injury should be allowed to benefit from the injury caused to others..." and after noting systemic concerns surrounding third-party funding, including an increase in frivolous or unmeritorious claims and impacts on settlements, suggested that increased transparency or an outright ban may be considered to deal with these concerns. [10:49:26]. Burkina Faso noted the ethical and other concerns regarding third-party funding in ISDS said that potential regulations, or a ban may be an appropriate result. [16:25:59]. Kenya raised the question of whether third-party funding should be banned in ISDS. [16:28:31]. South Africa, noting the increase in funding of nonpecunious investors, the financial value of claims being funded, and the targeting of certain profiles of countries, along with the significant impact that funders can have on case management and settlement, called for third-party funding to be seriously addressed, and noted Kenya's call for a detailed analysis as to what can be done, including a ban, or a very comprehensive transparency requirement including the terms of the funding agreement and ethical requirements [16:46:23]. India stated "third-party funding... has the potential to derail the system from its very objective of providing justice." [10:24:31]. Working Group III 37 th Session, Audio recordings (April 1, 2019) < https://icms.unov.org/CarbonWeb/public/uncitral/speakerslog/9e4160d4-6cef-4de6-83c0-d9c4645bf253> accessed April 30, 2019. Uruguay noted that given the option between regulation and a ban it supports regulation, and if banning third-party funding were not difficult, this is the option that it would choose. [12:06:31]. Morocco raised concerns about the possibility of speculative and abusive use of third-party funding by investors and while awaiting the adoption of rules that could effectively regulate third-party funding, propose a ban on third-party funding in context of UNCITRAL reform. [12:10:15]. Argentina intervened to remind delegations that a ban remains on the table. [12:28:20]. 
their 2018 bilateral investment treaty. ${ }^{169}$ And, as noted above, the United States bans third-party funding of domestic claims against the federal government.

To the extent states and arbitral institutions choose not to ban third-party funding, the impact that it can have on investment treaty arbitration and the various policy aims and interests it can impact strongly suggests introduction of comprehensive regulation that is meaningfully crafted to avoid the unintended and undesirable effects caused by third-party funding in ISDS.

\subsection{REGULATE THIRD-PARTY FUNDING}

When it comes to regulating third-party funding and third-party funders, there is a wide range of possibilities. Opinions about the need for various regulatory options will likely be rooted in and dependent on differences in perceptions about the various concerns surrounding third-party funding as well as what desirable policy responses should be. ${ }^{170}$

For example, if potential conflicts of interest as between arbitrators and funders are the only concern, it may be sufficient to mandate disclosure of the existence of funding and the identity of the funder (which should also include information about relevant actors in the corporate family). If the concern about third-party funding relates to the role of the funder in situations in which states struggle to enforce awards for costs, rules on security for costs may be desirable, and, particularly in the case of potentially impecunious claimants, the ability to understand when and under what circumstances the funder has a contractual obligation to fulfill a cost award, and relatedly, what rights the funder has to terminate the funding agreement, might also be useful. ${ }^{171}$

Additionally, if the concern surrounds the ability of the funder to exercise influence or control over the management of the claim, rules limiting such roles would be important. ${ }^{172}$ Here it is helpful to note that an important distinction between contingency fee or pro bono arrangements on the one hand, and more traditional forms of third-party funding (i.e. non-recourse financial interest in the outcome of a case) on the other, is that in the former case the "funder" is itself subject to external

\footnotetext{
${ }^{169}$ Agreement for the Reciprocal Promotion and Protection of Investments between the Argentine Republic and the United Arab Emirates (signed 16 April 2018, not yet in force) art 24: Third Party Funding ("Third party funding is not permitted.).

${ }^{170}$ Funders themselves are not necessarily opposed to some forms of regulation. IMF Bentham, for example, explains "The dispute financing industry is in the process of reform in many of the jurisdictions in which we operate. We expect and embrace change and so we have welcomed the regulatory reviews and oversight that are taking place, and indeed have long called for appropriate regulation as our industry matures and expands to the mainstream.” IMF Bentham (n 30) 20 .

${ }^{171}$ Of course, liability for adverse cost awards could be built into any third-party funding transaction - everything has a price. However, funders rightly note that if they are forced to take the step of collateralizing these contractual obligations, either through escrow or a guarantee, this would significantly impact their business model - money in escrow or booked as a liability is not otherwise being used to earn a much higher return in another investment.

${ }^{172}$ See Steinitz (n 112) 1327-1330. Hong Kong's regulations surrounding third-party funding require the extent of control that the funder may exercise to be included in the funding agreement. Code of Practice for Third Party Funding of Arbitration, Hong Kong Arbitration Ordinance, No. 6, (2017), § 98(U) ("The funding agreement shall set out clearly: (1) that the third-party funder will not seek to influence the funded party or the funded party's legal representative to give control or conduct of the arbitration to the third-party funder except to the extent permitted by law; (2) that the third-party funder will not take any steps that cause or are likely to cause the funded party's legal representative to act in breach of professional duties; and (3) that the third-party funder will not seek to influence the arbitration body and any arbitral institution involved.").
} 
ethical and other regulations that prevents it from engaging in exploitative behavior. ${ }^{173}$ Lawyers are held to ethical standards by their bar, which include fiduciary obligations to act in their client's best interest. Third-party funders are not subject to this kind of oversight or regulation. While they do have obligations to their shareholders (in the form of maximizing profit) that may align with the interest of the funded party, this alignment of interests will not be true in all cases. Enforceable ethical rules may need to be developed regarding the attorney-client-funder relationship to ensure that funding structures are more fundamentally focused on the client's interest. ${ }^{174}$

In addition to suggesting that certain ethical duties be imposed on funders' relationships with funded parties, Maya Steinitz has also suggested that consumer protection and contract-design principles may be desirable to incorporate into funding agreements, that courts (or tribunals) should have supervision over relationships with funders, and that securities regulations should be tailored to address secondary markets in funded claims, among other helpful suggestions. ${ }^{175}$

Some early efforts to address the regulation (as opposed to ban) of third-party funding in ISDS have focused on these issues of conflicts and control. Singapore and Hong Kong, which otherwise ban third-party funding, have crafted regulations to permit, and regulate, third-party funding in arbitration. ${ }^{176}$ These jurisdictions impose ethical obligations related to funding, and also require that the existence and identity of the funder be disclosed to the tribunal and other parties, with the ability of the tribunal to order disclosure of the funding agreement in certain contexts. ${ }^{177}$ Hong Kong has also recently addressed the issue of control, generally prohibiting the funder from exercising control over the arbitration to the extent permitted by law. ${ }^{178}$ ICSID has proposed in the current draft of its rule revision proposal a requirement for a party to disclose the existence of funding and identity of the funder to the tribunal. It is possible that certain aspects of the funding agreement could be disclosed in certain circumstances. ${ }^{179}$

\footnotetext{
173 Steinitz (n 112) at 1327-30.

174 Ibid 1326.

175 Ibid.

${ }^{176}$ At least one third-party funder actively and publicly lobbied for these changes. Burford, 2017 Annual Report (n 63) 11 ("Until 2017, both Hong Kong and Singapore had prohibited litigation finance (except in insolvency), and indeed any form of risk-based litigation activity, including lawyers taking risk on their own fees. However, following significant education and lobbying by Burford, both jurisdictions passed legislation in 2017 that enabled litigation finance for arbitration.")

${ }^{177}$ In Singapore, the tribunal may order disclosure of certain details of the funding agreement "where appropriate, details of the third-party funder's interest in the outcome of the proceedings, and/or whether or not the third-party funder has committed to undertake adverse costs liability." SIAC Investment Arbitration Rules 2017, Article 24(L). Pursuant to the Hong Kong Code of Practice for Third Party Funding of Arbitration, "the funded party to an arbitration does not have any obligation to disclose details of the funding agreement except as required by the funding agreement, or as ordered by the arbitration body in an arbitration, or as otherwise required by law." Supra note 104 , Art 2.11 .

${ }^{178}$ Code of Practice for Third Party Funding of Arbitration, Hong Kong Arbitration Ordinance, No. 6, (2017), § 98(U) ("The funding agreement shall set out clearly: (1) that the third party funder will not seek to influence the funded party or the funded party's legal representative to give control or conduct of the arbitration to the third party funder except to the extent permitted by law; (2) that the third party funder will not take any steps that cause or are likely to cause the funded party's legal representative to act in breach of professional duties; and (3) that the third party funder will not seek to influence the arbitration body and any arbitral institution involved.").

179 The ICSID amendment proposal addresses third-party funding in Rule 13. ICSID, Proposals for Amendment of the ICSID Rules, Working Paper \#2, Volume 1 (March 2019). Paragraph 139 explains: "Some commentators suggested that AR 13 should require disclosure of the entire funding agreement. AR 13 requires disclosure of the fact of funding and the name of the funder only, as nothing further is required to achieve the purpose of the rule, avoidance of conflicts of interest. This approach is in line with current treaty practice and most other arbitration rules that address this topic.
} 
Beyond the issues of conflict and control, it is important to consider whether there are other regulatory options that might help ensure that the incentives and conduct of funders (and other actors in the system) align with the object and purpose of investment treaties. While, for instance, rules mandating disclosure of the identity of the funder may make it easier to identify conflicts of interest or other problematic relationships between arbitrators and specific funders, transparency alone will not address more systemic conflicts. For example, if a law firm derives secondary benefits because a client has received funding to advance an ISDS claim, certain conflicts may arise in cases where other law firm partners are either representing states or serving as arbitrators. Will such respondent counsel be as willing to argue, or such arbitrators as willing to decide, issues adverse to the interests of their claimant clients, including, for example, that third-party funders' interests are not "investments" the treaties were designed to protect and so are not entitled to recover under the treaty, or that third-party funders must themselves qualify as "investors" in order to successfully advance claims? These types of structural conflicts would not be resolved by disclosure of the existence of the funder, the funding agreement, or prohibitions on control. Rather, there would need to be other approaches, such as clear ethical rules on imputation of conflicts of interests.

Related issues that regulation of third-party funding could address relate to whether it is consistent with the treaties to:

- permit funders and funding models that encourage arbitration, provide broad rights of standing and broad interpretations of substantive standards, and push for large awards for expectation damages;

- permit funders and funding arrangements to exacerbate the asymmetries in power between the claimant and respondent in many ISDS disputes;

- create an industry of funders (separate from and in addition to individual claimants, attorneys, experts and arbitrators) that profits from and is likely to push (via lobbying and arbitration) for third-party-funding-friendly rules on standing, liability, and damages; and

- make it feasible and attractive for the FDI (or other) investor to monetize and sell its interest in a potential ISDS claim against the country in which it had invested.

Additional considerations relate to impact of funding on flows of investment across borders, and taxation of those flows. In an era when tackling problems of base erosion and profit shifting ${ }^{180}$ have gained heightened attention and urgency at national and international levels, and as policymakers and implementers are struggling to improve domestic resource mobilization and put in place human-rights aligned tax policies and practices, ${ }^{181}$ is it appropriate to permit third-party funders to secure payouts from public funds, while structuring their investments across affiliates

If the disclosure of further information about the third-party funding arrangement becomes relevant to another aspect of the proceeding, Tribunals have discretion under the general rules on evidence to order disclosure of relevant materials."

${ }^{180}$ More information available on the OECD/G20 Inclusive Framework on BEPS at <http://www.oecd.org/tax/beps/>.

${ }^{181}$ See e.g. Olivier De Schutter, 'Taxing for the Realization of Economic, Social and Cultural Rights' (May 2017) Institute for Interdisciplinary Research in Legal sciences (JUR-I), Center for Philosophy of Law (CPDR), CRIDHO Working Paper 2017/1; Center for Economic and Social Rights, 'Challenging Fiscal Abuse and Promoting Human Rights-Aligned Tax Policies'<http://www.cesr.org/human-rights-taxation> accessed April 29, 2019. 
and borders in ways that result in them paying absurdly low taxes (to any and all relevant governments). ${ }^{182}$

Overall, as discussed in this paper, there are a range of concerns about third-party funding that go beyond issues of case-specific conflicts of interest and protection of the claimant in the claimantattorney-funder relationship. These include third-party funding's potential to generate inordinate costs for developing states, its ability to impact outcomes in particular cases and to shift the boundaries of the law in more funder- and/or claimant-friendly ways, its impact on incentives to sue and related retention of FDI, and its propensity to exacerbate situations of regulatory chill and overdeterrence. In light of these issues, it is crucial to fully explore the actual and potential, positive and negative, intentional and unintentional, and discrete and systematic effects of third-party funding in ISDS, and consider a ban, or regulations, that address and avoid unwanted outcomes. While initiatives such as ICSID's have thus far failed to take on this challenge, the ongoing process in UNCITRAL's Working Group III on ISDS reform appears to be poised to take a more comprehensive look at a much broader range of concerns, with an outcome that may be correspondingly broad to thoroughly address them. ${ }^{183}$ Other states may similarly be exploring and addressing these issues in much greater depth on a bi- or multi-lateral basis. ${ }^{184}$

\subsection{PraCtiCAL ISSUES AND CHALLENGES}

Efforts to ban or regulate third-party funding will likely face hurdles and resistance. Supporters of the practice, for instance, argue for regulatory inaction or limited action on the ground that there is not adequate information about the practice to identify problems or propose solutions. ${ }^{185}$ It may be said, for instance, that the negative outcomes highlighted in this paper are largely theoretical and anecdotal, and are not widely documented; it may also be said that, as discussed above, rather than raising concerns, third-party funding plays a valuable social role in terms of leveling the playing field between disputing parties, ensuring that those harmed have their day in "court", and helping produce sound outcomes. Testing these pro and con arguments is undoubtedly desirable, and also undoubtedly difficult given the opacity surrounding the extent and nature of funders' involvement in ISDS cases. But the lack of data should not be a barrier to regulatory action. Given that it is funders who hold the information that would be crucial for dispelling concerns about, and demonstrating the value of, their practices, and that funders have not disclosed such information, the presumption should be that the concerns are valid. Unavailability of information should not be used to justify a laissez-faire approach when it is the potentially regulated entity that holds, but opts not to provide, the relevant information.

\footnotetext{
${ }^{182}$ E.g. Burford anticipates that its long-term tax rates will be in the low teens. 2018 Annual Report (n 27) 45. See also IMF Bentham (n 30) 74-76.

${ }^{183}$ UNCITRAL, Report of Working Group III (n 2).

${ }^{184}$ E.g. Argentina and the United Arab Emirates ban third-party funding in their recent bilateral investment treaty. Argentina/UAE treaty (n 169) art 24.

${ }^{185}$ In their respective submissions to ICSID relating to ICSID's arbitration rules revision process, for instance, Vannin Capital, Burford Capital, and Woodsford Litigation Funding, third-party funders of ISDS cases, stated that proposed rules requiring disclosures of the existence and identities of funders were unnecessary as there were not any known cases were third-party-funding-related conflicts were found to exist. Those submissions are available on ICSID's website <https://icsid.worldbank.org/en/amendments/Pages/Public\%20Inputs/input.aspx> accessed_April 16, 2019.
} 
Another argument that has been used to dismiss efforts to ban and/or regulate third-party funding in ISDS is that, given the challenges in defining precisely what it is we are talking about, and the sophisticated nature of funders whose products evolve and quickly cross definitional lines, ${ }^{186}$ it will be difficult if not impossible to articulate what it is that is banned or regulated. According to some, it is therefore better to do little or nothing than to seek to regulate an amorphous and constantly-shifting form of financing where the industry will outpace the regulators. ${ }^{187}$ Yet while it may be the case that the third-party financing industry, motivated by extreme levels of profit, has incentives to invest substantial resources to elude regulatory oversight, this is a poor reason to do nothing or to limit regulatory ambitions.

It is also argued that due to the atomized, multi-jurisdictional nature of ISDS and the entities and jurisdictions that do (and do not) govern it, regulatory efforts will be futile and/or hopelessly complicated. Indeed, part of the hurdle of regulating and enforcing prohibitions of or sanctions against third-party funding in ISDS is that the laws and policies of multiple jurisdictions may be relevant in any given case, including but not limited to: the home country jurisdiction of the funder, the jurisdiction where the investor is incorporated, the jurisdiction of the funding vehicle (along with any interim jurisdictions in the corporate structure), the host-country jurisdiction, the jurisdiction of the seat of the arbitration, and the jurisdiction where enforcement is sought. To the extent some jurisdictions and not others implement some form of regulation (or even less formal public policy opposition), the ease of jurisdiction-shopping means that funders may be able to use creative corporate structures to avoid or mitigate oversight. Moreover, to the extent arbitration rules mandate different levels of transparency or regulation of third-party funders, claimants may take this into account when choosing under which rules to arbitrate. While the multijurisdictional aspect of ISDS is indeed a challenge, the challenge of regulating financial services and industries is not limited to third-party funding, but is a task put to regulators worldwide in many multijurisdictional contexts. Collective efforts by states, arbitral institutions, and other actors involved in policy making and enforcement, ${ }^{188}$ can result in shared understanding of acceptable practices and can produce rules capable of achieving regulatory objectives. And even in the absence of full consensus on the problems that need to be addressed and the appropriate way forward for doing so, and even without certainty that foolproof mechanisms will ultimately be identified for preventing regulatory arbitrage and races to the bottom, ${ }^{189}$ it is nevertheless important to thoughtfully address issues and options. These arguments reflect real challenges, but they do not justify a do-nothing approach. As we have learned from other forms of financial services regulation, definitions and sanctions are possible where there is a will to construct and enforce them.

\footnotetext{
${ }^{186}$ See, e.g., Vannin Capital and Burford Capital (n 185) (discussing how the proposed definition of did not reflect the current state of the sophisticated and complex litigation finance market).

${ }^{187}$ See Catherine A. Rogers, Ethics in International Arbitration (Oxford University Press 2014) 192-194.

${ }^{188}$ Effectively banning third-party funding in ISDS will likely require a multi-pronged approach that would require bans (and enforcement thereof) by arbitral institutions, in treaties themselves, and also at the domestic level with respect to ethical rules governing lawyers as well as domestic law, particularly where such law applies as the seat of arbitration or jurisdiction of enforcement.

${ }^{189}$ As David Gaukrodger has indicated, arbitration institutions may be competing for business from investors, and such competition may encourage them to adopt rules, practices and policies more favorable to investor claimants. David Gaukrodger, 'Appointing Authorities and the Selection of Arbitrators in Investor-State Dispute Settlement: An Overview' (March 2018) OECD Consultation Paper, 12-16 (discussing some key features of arbitration institutions and the possibility and implications of competition among them). Thus, it is not inconceivable that some institutions will decline to discipline the practice of third-party funding on the ground that liberal rules regarding its use will result in more claims being brought to their facilities.
} 


\section{Conclusion}

Third-party funding in ISDS raises a host of policy issues that are specific to this unique context. Thus, justifications for third-party funding that may apply in other fora do not necessarily apply in this particular area of claims and liability. While certain initiatives are exploring and addressing important issues that arise with respect to third-party funding in the ISDS context, such as conflicts of interests and security for costs, there is a series of more systemic concerns that merit further attention and analysis. Initiatives to date have failed to adequately assess the costs and benefits of third-party funding against the objectives of the treaty system the objectives of which it purports to, or should, advance.

This paper has set forth issues that should be of paramount importance to states and other stakeholders as they consider whether and how to regulate or ban third-party funding in ISDS. There are serious causes for concern about its impacts on investors' incentives, on respondent states' exposure, liability, and responses to ISDS claims, and on the investment law system itself. In the absence of information to dispel these concerns, and in light of the fact that funders hold much of the information relevant for a deeper analysis of the issues, precaution should govern policy approaches. ${ }^{190}$

To date, the only parties that third-party funding seems to be benefiting are the investment law bar, claimants, and funders themselves. As arbitrator Gavan Griffith bluntly stated, from the perspective of a funder, third-party funding in ISDS is a "gambler's Nirvana: Heads I win, tails you lose." 191 Whether the objectives of investment treaties and global economic development should be ceded to the profit motive of investment funds is a question of critical importance that must be addressed in the context of all ISDS reform discussions.

\footnotetext{
${ }^{190}$ Garcia (n 162) 2930 (advocating precautionary approach to third-party funding regulation in view of potential risks and magnitude of funding already involved).

${ }^{191}$ RSM Production Corporation v. Saint Lucia, Decision on Saint Lucia’s Request for Security for Costs, Assenting reasons of Gavan Griffith, ICSID Case No. ARB/12/10 (Aug. 13, 2014) 13.
} 